\title{
SOEP
}

SOEPpapers

SOEPDanors
on Multidisciplinary Panel Data Research

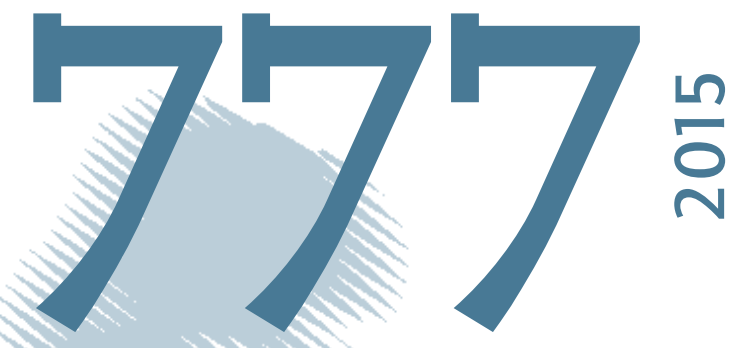

\section{The Impact of Short- and Long-term Participation Tax Rates on Labor Supply}

Charlotte Bartels and Nico Pestel 
This series presents research findings based either directly on data from the German SocioEconomic Panel study (SOEP) or using SOEP data as part of an internationally comparable data set (e.g. CNEF, ECHP, LIS, LWS, CHER/PACO). SOEP is a truly multidisciplinary household panel study covering a wide range of social and behavioral sciences: economics, sociology, psychology, survey methodology, econometrics and applied statistics, educational science, political science, public health, behavioral genetics, demography, geography, and sport science.

The decision to publish a submission in SOEPpapers is made by a board of editors chosen by the DIW Berlin to represent the wide range of disciplines covered by SOEP. There is no external referee process and papers are either accepted or rejected without revision. Papers appear in this series as works in progress and may also appear elsewhere. They often represent preliminary studies and are circulated to encourage discussion. Citation of such a paper should account for its provisional character. A revised version may be requested from the author directly.

Any opinions expressed in this series are those of the author(s) and not those of DIW Berlin. Research disseminated by DIW Berlin may include views on public policy issues, but the institute itself takes no institutional policy positions.

The SOEPpapers are available at http://www.diw.de/soeppapers

\section{Editors:}

Jan Goebel (Spatial Economics)

Martin Kroh (Political Science, Survey Methodology)

Carsten Schröder (Public Economics)

Jürgen Schupp (Sociology)

Conchita D'Ambrosio (Public Economics)

Denis Gerstorf (Psychology, DIW Research Director)

Elke Holst (Gender Studies, DIW Research Director)

Frauke Kreuter (Survey Methodology, DIW Research Fellow)

Frieder R. Lang (Psychology, DIW Research Fellow)

Jörg-Peter Schräpler (Survey Methodology, DIW Research Fellow)

Thomas Siedler (Empirical Economics)

C. Katharina Spieß (Education and Family Economics)

Gert G. Wagner (Social Sciences)

ISSN: 1864-6689 (online)

German Socio-Economic Panel Study (SOEP)

DIW Berlin

Mohrenstrasse 58

10117 Berlin, Germany

Contact: Uta Rahmann | soeppapers@diw.de 


\title{
The Impact of Short- and Long-term Participation Tax Rates on Labor Supply*
}

\author{
Charlotte Bartels
}

Freie Universität Berlin

Nico Pestel

$I Z A$ and $Z E W$

\begin{abstract}
:
Generous income support programs as provided by European welfare states have often been blamed to hamper employment. This paper investigates the importance of incentives inherent in the tax-benefit system for the individual decision to take up work. Using German microdata over the period 1993-2010 we find that recent reforms in Germany increased work incentives at the extensive margin measured by the Participation Tax Rate (PTR), particularly for low income individuals. Work incentives are even higher if the time horizon is extended to more than one year, pointing at an overestimation of the disincentives by standard measures. Regression analysis reveals that a decrease in the PTR increases the likelihood of taking up work significantly.
\end{abstract}

JEL Classification: H24, H31, J22, J65

Keywords: labor force participation, work incentives, welfare, unemployment insurance, income taxation

\section{Corresponding author:}

Charlotte Bartels

Freie Universität Berlin

Boltzmannstr. 20

14195 Berlin

Germany

E-mail: charlotte.bartels@fu-berlin.de

\footnotetext{
* The paper benefited from the comments of the editor and one anonymous referee. We thank Timm Bönke, Giacomo Corneo, Sebastian Eichfelder, Frank Fossen, Peter Haan and Victor Steiner as well as participants of the SSCW 2012, Verein für Socialpolitik 2012, ECINEQ 2013, IIPF 2014, SEEK 2014 and 13th Finanzwissenschaftler Workshop 2014 for helpful comments and suggestions.
} 


\section{Introduction}

In many European welfare states, major reforms have been undertaken in the last three decades to tackle the enduringly high unemployment rates. Under the general impression that generous benefits and high marginal taxes were to blame for low incentives to take up work, out-of-work benefits have been reduced and income taxes cut. These reform efforts are backed by a wide range of empirical studies on labor supply elasticities showing that behavioral responses are higher at the extensive margin than at the intensive margin, particularly for low-income individuals. Hence, a tax-benefit design misshapen at the extensive margin may create high efficiency costs.

In Germany, rising unemployment after reunification in 1990 ushered in a period of labor market and tax reforms. Beginning in 1994, eligibility for unemployment benefits was tightened and sanctioning mechanisms introduced to push the unemployed into work. Personal income tax reforms between 1998 and 2005 substantially reduced marginal and average tax rates particularly relieving the rich (Corneo, 2005). The most radical changes, the so-called Hartz reforms, were introduced between 2003 and 2005 slashing out-of-work benefits for low-income individuals and long-term unemployed. However, the latter effect becomes only evident, when analysing work incentives over several years.

This paper estimates work incentives in Germany at the extensive margin by computing Participation Tax Rates (PTR) - a work incentive measure derived from optimal tax theory - and examines the extent to which the presumed increase of work incentives contributed to raise the probability for the unemployed to take up work. First, we extend the analysis of work incentives to more than one year. A three-year period is chosen to lift the time horizon above a minimum of two years but maximizing the sample size of the balanced panel at the same time. Thereby, important aspects can be included in the analysis which individuals maximizing utility over time might consider: A working individual can experience earnings growth over time driven by on-the-job-training and tenure. In contrast, a non-working individual receives benefits from unemployment insurance or social assistance which are determined by institutional rules. In Germany, benefits from unemployment 
insurance decline with the duration of unemployment. Hence, income differences between working and non-working individuals tend to widen when extending the measurement period. Moreover, human capital depreciation during unemployment reduces future earnings potential. Two scenarios are developed in order to include human capital depreciation into the PTR measure.

PTRs are computed for all individuals in the labor force independent of their labor market status and demographic subgroups such as gender, employment level and household type. Women are more likely to work part-time, particularly in marginal employment, and are, thus, less often eligible for unemployment benefits than men which in turn may generate lower PTRs. These may also vary over household types. The financial reward for job take-up is largely determined by the effect of joint taxation and benefit withdrawal in the presence of a second earner and/or other income sources than labor earnings.

The main findings are as follows: First, long-term PTRs are significantly lower than short-term PTRs. Hence, standard measures overestimate the disincentives created by the German tax-benefit system. Three-year PTRs vary between $50 \%$ and $65 \%$ depending on the earnings level, whereas one-year PTRs are 70-80\%. Second, the Hartz reforms reduce PTRs, particularly for low-income women. Their long-term PTR declines from around $40 \%$ to about $30 \%$. Third, including human capital depreciation decreases the PTR, but the difference to the baseline scenario becomes negligible after the reforms. Fourth, a lower PTR significantly increase the probability to take up work in a time period of major changes in the German tax-benefit system towards higher work incentives.

The paper is organized as follows: A brief literature review is given in Section 2. Data and basic concepts regarding the measurement of short-term and longterm PTRs are outlined in Section 3. Section 4 provides an extensive discussion of our results for short-term and long-term PTRs in Germany 1993-2010 by earnings decile, earner type, age and gender and identifies driving factors behind PTRs in Germany. The estimation strategy and regression results are presented and discussed in Section 5. Section 6 concludes. 


\section{Literature Review}

The literature on labor supply and optimal taxation distinguishes labor supply responses at the extensive and at the intensive margin. After the seminal contribution of Mirrlees (1971) on optimal taxation at the intensive margin, Diamond (1980) developed an optimal tax model with labor supply responses at the extensive margin. Saez (2002) first incorporated both responses at the intensive and extensive margin. In optimal tax theory, work incentives inherent in the tax-benefit system are captured by the Effective Marginal Tax Rate (EMTR) at intensive margin and the Participation Tax Rate (PTR) at the extensive margin. Diamond (1980), Saez (2002) and, more recently, Jacquet et al. (2013) find that the optimal PTR can be negative for lower income levels. The empirical literature has shown that the behavioral response at the extensive margin exceeds the response at the intensive margin. In particular, low-educated men and single mothers/women reveal higher and married women lower extensive margin elasticities (see Chetty et al., 2013, Meghir and Phillips, 2010, for an overview).

Both the growing theoretical literature and the empirical results on the size of the response at the extensive margin triggered a number of studies estimating PTRs for various tax-benefit systems. Several studies have analyzed PTRs across European countries applying tax-benefit rules of 1998 and for the UK over time. Cross-country studies on PTRs in EU countries are Immervoll et al. (2007), Immervoll et al. (2009) and O'Donoghue (2011). These studies rely on the simulation model EUROMOD based on the tax-benefit rules prevailing in the year 1998. Country studies on PTRs are, e.g., Dockery et al. (2011) for Australia, Adam et al. (2006) and Brewer et al. (2008) for UK as well as Pirttillä and Selin (2011) for Sweden. However, all contributions are based on a time horizon of only one year.

Usually, empirical studies on work incentives examine their effect on either aggregate unemployment, unemployment duration or labor market participation within particular social insurance programs such as pensions or sickness pay. To our knowledge, we are the first to study the effect of a work incentive measure incorporating the entire tax-benefit system on the probability to take up work. 


\section{Method and Data}

\subsection{Data}

The analysis is based on a subsample from the SOEP survey years 1994 to 2011 with incomes from 1993 to 2010. The SOEP is a representative panel study containing individual and household data in Germany from 1984 onwards and was expanded to the New German Laender after German reunification in 1990. All household members are interviewed individually once they reach the age of 16.1

The sample only includes individuals who are aged between 25 and 54 to avoid distortions due to early or partial retirement. Individuals who are self-employed or civil servants and, as a consequence, did not necessarily contribute to unemployment insurance are dropped as are disabled individuals. Only individuals belonging to households classifiable as single, single parent or couples with or without children are included. Furthermore, employed individuals with earnings below $33 \%$ of the marginal employment threshold are dropped. Households enter the sample twice, if both adults meet the requirements outlined above.

Participation decisions are largely correlated with characteristics like gender, marital status and number of other household members. Figure 1 displays the share of individuals taking up work switching their labor market status from nonemployment $U$ to employment $E$. Men's probability of taking up work from one year to the next fluctuates around 3\% until 2005 and around 3.5\% thereafter. Women are more likely to take up work with the probability fluctuating around $4 \%$ which reflects increasing female labor market participation in Germany during this period.

Household earner types reveal both different patterns for men and women and change over time as depicted by Figure 2, Women are more likely to be the second earner working part-time and, consequently, earning less than their mostly full-time working husband. The share of male and female single households increases over time, but the majority of the observed men and women still lives in families. The share of female sole earners increases slightly whereas the share of their male counterparts decreases. Women are more likely to be a working single parent, whereas

\footnotetext{
${ }^{1}$ See Wagner et al. 2007) for further information on the SOEP.
} 
Figure 1

\section{Probability of taking up work (UE)}

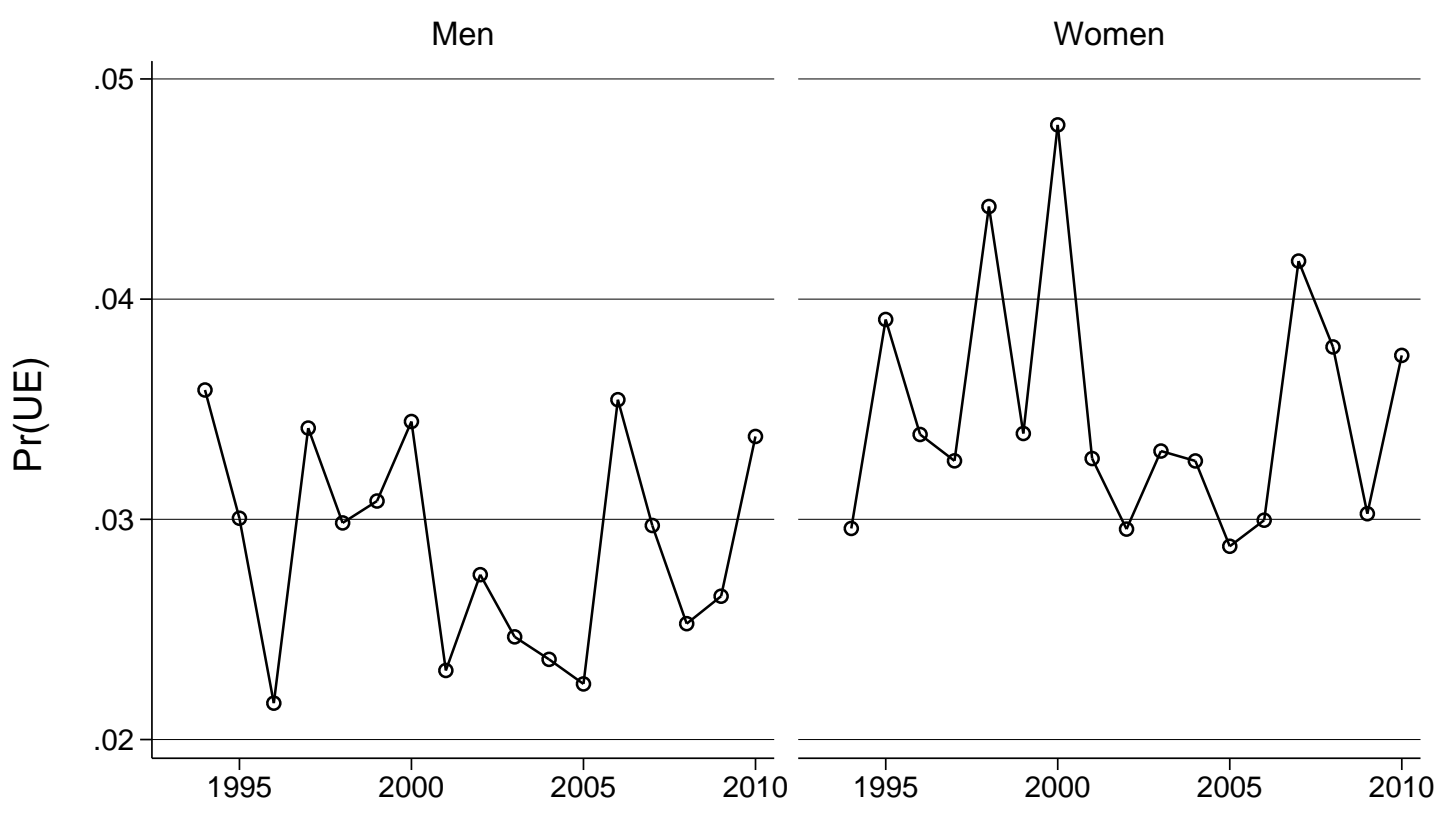

Source: SOEPv29 \& IZA MOD, own calculations.

men are more likely to have a working partner. 
Figure 2

\section{Composition of earner households}

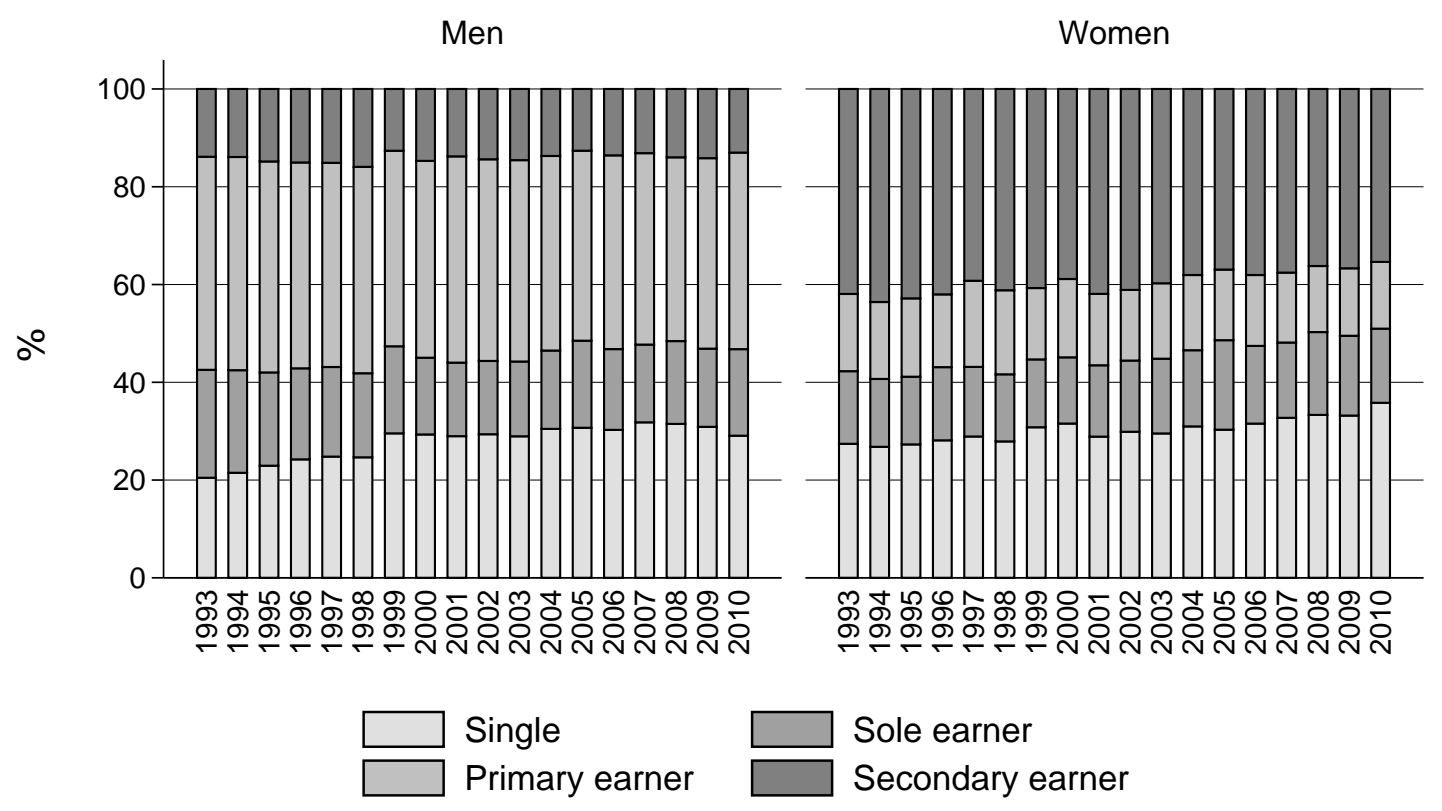

Source: SOEPv29 \& IZA MOD, own calculations.

\subsection{Measuring Participation Tax Rates}

\subsubsection{Standard Participation Tax Rates}

As a context for our empirical analysis we assume that the individual $i$ faces a binary choice between the two labor market states $E$ employed or $U$ unemployed. The PTR measures the change in household net taxes from labor market state $E$ to $U$ as a fraction of individual earnings in labor market state $E$. Net taxes $T$ paid by the household $h$ are income taxes $t_{h}$ including social security contributions reduced by benefits $b_{h}$. Taxes and benefits are based on the household context for three reasons. First, the loss of earned income in labor market state $U$ may not only trigger off eligibility rights for the unemployed individual but for other household members as well. Second, joint taxation in Germany requires to consider a married couple as a unit and to assess taxes on the basis of household income. Third, the impact of a change in overall household income on taxes and benefits takes the extent of income brought in by other household members and by other income sources into account. An annual PTR can thus be denoted as 


$$
P T R_{i h}=\frac{T\left(y_{h}^{E}\right)-T\left(y_{h}^{U}\right)}{y_{i}^{E, w}},
$$

where $y_{h}^{E}$ is gross household income, $T\left(y_{h}^{E}\right)$ is household net taxes and $y_{i}^{E, w}$ is individual labor earnings if the individual is in labor market state $E$. Gross household income is the sum of labor earnings, asset income, private transfers, private pensions and social security pensions of all household members. $y_{h}^{U}$ is gross household income and $T\left(y_{h}^{U}\right)$ is household net taxes if the individual is in labor market state $U$ having zero individual labor earnings.

If household net taxes are equal for both labor market states, then the PTR is zero and incentives to take up work are not distorted. But a welfare state providing income support in state $U$ usually leads to $t_{h}^{U}<b_{h}^{U}$ resulting in $T\left(y_{h}^{U}\right)<0$ as unemployment benefits will surpass taxes paid for the declined household income $y_{h}^{U}$. In sum, the change in net taxes will be positive in presence of a welfare state and the PTR will be higher than zero for most individuals. The higher the PTR, the more do generous income support programs reduce the financial gain from working. The PTR is one, if the change in net taxes $T\left(y_{h}^{E}\right)-T\left(y_{h}^{U}\right)$ (numerator) is equal to individual earnings $y_{i}^{E, w}$ (denominator). In this case, there is no financial gain from working. If out-of-work income support exceeds earnings, then the PTR can be even greater than one.

In order to obtain a PTR for all individuals in the labor force independent of their observed labor market status $E$ or $U$, the non-observed state has to be simulated. For the simulation, it is assumed that a change in one partner's labor supply behavior, i.e., giving up or taking up a job, does neither affect the labor supply behavior of the other partner nor household income from other sources than labor. This procedure is standard in the PTR literature (see, e.g., Immervoll et al., 2007). We employ three simulation scenarios:

1. We take observed individual earnings $y_{i}^{E, w}$ and gross household income $y_{h}^{E}$ in $E$ from the SOEP data. Gross household income in $U$ is then given by setting individual earnings to zero and holding constant other household members' labor income and household income from other sources, i.e., $y_{h}^{U}=y_{h}^{E}-y_{i}^{E, w}$. 
However, this simulation scenario misses all those with zero earnings.

2. We simulate $y_{i}^{E, w}$ for 20 hours of work for all individuals in the subsample independently of their observed earnings and compute $y_{h}^{E}$ and $y_{h}^{U}$ accordingly. Hourly wages are estimated by a standard Heckman procedure Heckman, 1979).

3. We simulate $y_{i}^{E, w}$ for 40 hours of work for all individuals in the subsample independently of their observed earnings and compute $y_{h}^{E}$ and $y_{h}^{U}$ accordingly. As for [2.], hourly wages are estimated by a standard Heckman procedure.

In a second step, we then apply the tax-benefit rules of the respective year to obtain household taxes $t_{h}$ and public transfers $b_{h}$ for both states $E$ and $U$ assuring consistent assumptions regarding deductions etc. For example, household taxes paid in state $U$ are the sum of income tax $t_{h}^{U, i n c}$ assessed on the basis of $y_{h}^{U}$, solidarity surcharge $t_{h}^{U, S}$ and social security contributions $s_{j}^{U}$ on spouse's earnings $y_{j}^{E, w}$ if the spouse $j$ is working in $E$. Household public transfers are the sum of unemployment benefits, unemployment assistance, maternity benefits, social assistance, housing allowances and child benefits. A potential increase in benefits when changing from $E$ to $U$ will occur for unemployment benefits, unemployment assistance, social assistance and housing allowances. In contrast, maternity benefits and child benefits do not depend on household income and remain constant between $E$ and $U$. All simulations are based on IZA $\Psi$ MOD, which is a microsimulation model for Germany including a tax-benefit calculator for all years since the 1990s.2 Further details on the regulations of the German tax-benefit-system are given in Appendix A.

\subsubsection{Long-term Participation Tax Rates}

The standard approach assesses work incentives over a one-year time horizon. But economic theory on household economics predicts income pooling and budget smoothing over long periods. Individuals may thus condition their participation decision not only on next year's expected income, but rather on a longer time horizon. A working individual can achieve consecutive raises in earnings carving out a career.

\footnotetext{
${ }^{2}$ See Löffler et al. (2014) for a documentation of the simulation model.
} 
In contrast, a transfer dependent individual receives a stable transfer income fixed by the legislator, which only changes in the wake of reforms. Earnings-related unemployment benefits are only paid during a limited period of time in Germany, i.e., during one year for most individuals. This drop in benefits after exhaustion of earnings-related unemployment benefits can only be accounted for by extending the time horizon. Hence, while short-term PTRs are calculated for one year, longterm PTRs are based on three years to shed light on work incentives in the longer term. A three-year period is chosen to lift the time horizon above a minimum of two years but maximizing the sample size of the balanced panel at the same time. To calculate long-term PTRs a long-term income measure is needed. Long-term PTRs of the observed simulation scenario are based on a balanced panel including only individuals who were employed during all three years.

The long-term PTR is computed as the Net Present Value (NPV) of PTRs over the respective period. Individual earnings $y_{i t k}^{w}$ and household net taxes $T\left(y_{h t k}\right)$ in year $k$ with base year $t$ is discounted by $d_{t k}$ which is the inverse of the Consumer Price Index (CPI) increase $\pi_{t k}$ from the base year $t$ to year $k$. The PTR in the long-term $l$ is defined as

$$
\begin{aligned}
P T R_{i h t}^{l} & =\frac{N P V\left(T\left(y_{h}^{E}\right)-T\left(y_{h}^{U}\right)\right)}{N P V\left(y_{i}^{E, w}\right)} \\
& =\frac{\sum_{k=1}^{K} d_{t k} \cdot\left[T\left(y_{h k}^{E}\right)-T\left(y_{h k}^{U}\right)\right]}{\sum_{k=1}^{K} d_{t k} \cdot y_{i k}^{E, w}}
\end{aligned}
$$

\subsubsection{Participation Tax Rates with Human Capital Depreciation}

Choosing labor market state $U$ not only triggers potential transfers but also carries costs such as matching costs to find a new employer, stigma, unemployment scarring and reduced re-entry earnings as a result of human capital depreciation (hcd). Not including the costs of non-participation would overestimate the disincentives, particularly if costs accumulate over time spent in non-participation. While the loss in specific human capital is a once-for-all phenomenon due to the separation from the job, the loss in general human capital increases with the duration of non-participation (Mincer and Ofek, 1982). Hence, the baseline scenario is slightly 
modified to two alternative scenarios. In scenario 1, the individual now chooses between not working in the first year and working the two subsequent years $(U, E, E)$ or not working at all $(U, U, U)$. In scenario 2 , the individual chooses between not working for two years and working the year after $(U, U, E)$ or not working at all $(U, U, U)$.

For the simulation of depreciated earnings at re-entry it is assumed that earnings decline by $\alpha=2 \%$ per year of non-participation 3 Depreciated earnings at re-entry in $k_{2}$ (scenario 1 ) or in $k_{3}$ (scenario 2 ) are computed as a fraction of earnings given in the data and are defined as

$$
y_{i}^{E_{k}, w, h c d}=y_{i}^{E_{k}, w} \cdot(1-\alpha)^{k-1} \quad \text { with } k=1,2,3
$$

where $k$ indicates the number of periods being unemployed.

\section{Results for Participation Tax Rates}

Several factors lead to variation of PTRs among the population. Individual earnings is a major determinant in the denominator of the PTR-formula. The PTR is higher, the lower the wage and/or weekly working hours. On the other hand, real wage growth may lead to lower PTRs and higher work incentives. Apart from earnings, PTRs heavily depend on the household context that determines the change in net household taxes between $E$ and $U$ in the numerator of the PTR-formula. High PTRs can be generated by both high out-of-work income provided by the welfare state and large reductions in household net taxes when changing to state $U$. Both terms strongly depend on the level of spouse's earnings and other household income sources.

The PTR can be interpreted as the sum of the in-work tax rate and the outof-work gross replacement rate. A single median earner, whose only income source is labor income, may serve as a stylized example to illustrate this interpretation.

\footnotetext{
${ }^{3} \mathrm{~A}$ number of studies estimates the earnings penalty or atrophy rate per year of nonparticipation. Results are mostly around or slightly higher than 1\% (e.g. Kim and Polachek, 1994), but some are even as high as 11\% (Gregory and Jukes, 2001) earnings reduction per year.
} 
A PTR of $80 \%$ for a single earning 24,000 Euro annually results from an in-work tax rate equal to $\frac{11,000}{24,000}=46 \%$ and an out-of-work gross benefit ratio equal to $\frac{8,200}{24,000}=34 \%$. Net taxes in $E$ result from taxes on earnings of 11,000 Euros and zero transfers. Net taxes in $U$ result from zero taxes and unemployment benefits of 8,200 Euro. The net financial gain of taking up a job with a salary of 24,000 Euro is 4,800 Euro (20\% of 24,000 ). This may appear very small at the first sight. But indeed, the German tax-benefit system creates high PTRs in European comparison. Immervoll et al. (2007) find a median earner PTR slightly above $70 \%$ in Germany, France, Sweden and Finland. Solely Denmark has higher PTRs. Median earner PTRs in United Kingdom, Ireland, Austria and Italy are in the range of $50 \%$ to $60 \%$. The German median earner faces comparably high taxes and social security contributions combined with generous unemployment benefits. But as we will see in the following, PTRs vary quite a lot over the working age population and over time.

\subsection{Short-term Participation Tax Rates by Earnings Decile}

The development of short-term PTRs by earnings decile, gender and simulation scenario over time is shown in Figure 3. Each graph presents median PTRs within an earnings decile between 1993 and 2010. We first comment on PTRs based on observed hours. Two features stand out.

First, PTRs increase with earnings. Men and women in the top decile face a PTR of about $80 \%$, whereas the PTR in the lowest decile is only about $60-70 \%$ regardless of the simulation scenario. This occurs because of both lower benefits in $U$ and a lower tax wedge between $E$ and $U$ in the lowest decile. The number of those eligible for unemployment benefits in the bottom decile is remarkably smaller than for other deciles because their earnings are below the social security threshold. Single and primary earners who are not eligible for unemployment benefits in the lowest decile most likely are eligible for social assistance. Secondary earners - mostly female - are often neither eligible for unemployment benefits nor for social assistance because of the breadwinner's high earnings. As secondary earners are mostly women, the bottom decile of the female earnings distribution has by far the lowest PTRs. 
Furthermore, lower earnings in the lowest decile imply that household income falls less when the individual is in state $U$ which in turn amounts to smaller tax differences between $E$ to $U$.

Second, short-term PTRs at the bottom declined over time, but remained rather stable for higher earnings levels. Reduced eligibility for unemployment benefits combined with limited claims for social assistance in the lowest decile contributed to reduce PTRs and increase work incentives for this group. With the growth of the low-income sector an increasing number of individuals in the bottom decile is marginally employed and earns less than the social security threshold $f^{4}$ The threshold of the bottom decile of men hardly changed over time. It was, e.g., 1,158 Euro in 1995 and 1,160 Euro in 2006. The threshold of the women's bottom decile decreased from 668 Euro in 1995 to 430 Euro in 2006 which reflects both employment growth in the low-income sector and increased female participation in marginal employment. Finally, the social security threshold itself was raised remarkably from 325 to 400 Euro in 2003 tightening up eligibility for low-income earners even further 5 As a result, hardly any women in the bottom decile is eligible for unemployment benefits after the reforms. Marginally employed are exempt from the progressive income tax such that the tax wedge between $E$ and $U$ is zero ${ }^{6}$ Hence, median PTRs for women in the bottom decile are zero in some years since both changes in taxes and benefits between $E$ and $U$ are zero and work incentives are undistorted by the tax-benefit system. Reduced eligibility for unemployment benefits similarly applies to the simulation scenario with 20 hours of work where PTRs decrease after 2004 for men and women. The developments in Germany stand in contrast to the UK where Adam et al. (2006) attribute the gradual strengthening of work incentives from the early 1980 s to the late 1990 s to growth of real earnings.

Empirically, the behavioral response captured by the extensive labor supply

\footnotetext{
${ }^{4}$ In contrast, the two top earnings deciles experienced substantial earnings growth. See Appendix Figure B.1 for the evolution of earnings decile thresholds over time.

${ }^{5}$ Moreover, the time period considered for unemployment benefit eligibility (12 month record of employment subject to social security contributions) was reduced from three to two years as of 2006. See Appendix A for further details on the legislative changes in the German tax-benefit system.

${ }^{6}$ Earnings of marginally employed are subject to a lump sum wage tax of $2 \%$ paid by the employer.
} 
elasticity is higher for low-income individuals.7 The higher the extensive elasticities for a certain group, the lower is the optimal PTR for the group 8 I.e., work incentives inherent in the tax-benefit system should be higher and PTR lower for those who are more prone to decide for unemployment and transfer recipience instead of labor market participation. Lower PTRs for the bottom decile in Germany resulting in higher work incentives may thus point in the right direction.

In sum, all three simulation scenarios produce PTRs similar in magnitude. Only the bottom decile has lower PTRs in the simulation scenario with positive observed earnings only. Observed earnings in the bottom decile are lower than simulated earnings for 20 or 40 weekly working hours because many low-income earners, particularly women, are marginally employed and work less than 20 hours per week. Consequently, the share of those eligible for unemployment benefits is higher when simulating 20 hours of work for everyone in the sample, even higher when simulating 40 hours of work and the tax wedge between $E$ and $U$ increases.

Individuals in the lowest earnings decile face a greater range of PTRs than higher earnings deciles as can be taken from Figure 4. This is due to the aforementioned division of the lowest decile into sole and primary earners eligible for social assistance and secondary earners not eligible for any out-of-work benefits and negligible tax wedges between $E$ and $U$. Women are overrepresented at the bottom of the joint earnings distribution and men are so at the top. E.g., in 1995 and 2006 there are $72 \%$ women and $28 \%$ men in the bottom decile. Up from the 5 th decile, men are in the majority. In the top decile, $72 \%$ are men and only $28 \%$ women. This division barely changes over time. Interestingly, some PTRs in the bottom decile are negative in 2006 which coincides with the theoretical results of Diamond (1980), Saez (2002) and Jacquet et al. (2013). This is due to the additional child benefit (Kinderzuschlag) which is an in-work benefit introduced in 2005 to raise the household income of working families above the threshold of social assistance. $!^{9}$

\footnotetext{
${ }^{7}$ The extensive labor supply elasticity measures the share of employed workers who decide to leave the labor force when the difference between net income in $E$ and $U$ decreases by 1 percent (Saez, 2002).

${ }^{8}$ Brewer et al. (2008) refer to the Ramsey principle of optimal taxation that commodities with relatively more elastic demands should be subject to relatively lower tax rates.

${ }^{9}$ See Appendix A for further details.
} 
Figure 3

PTR (short): Median by earnings deciles

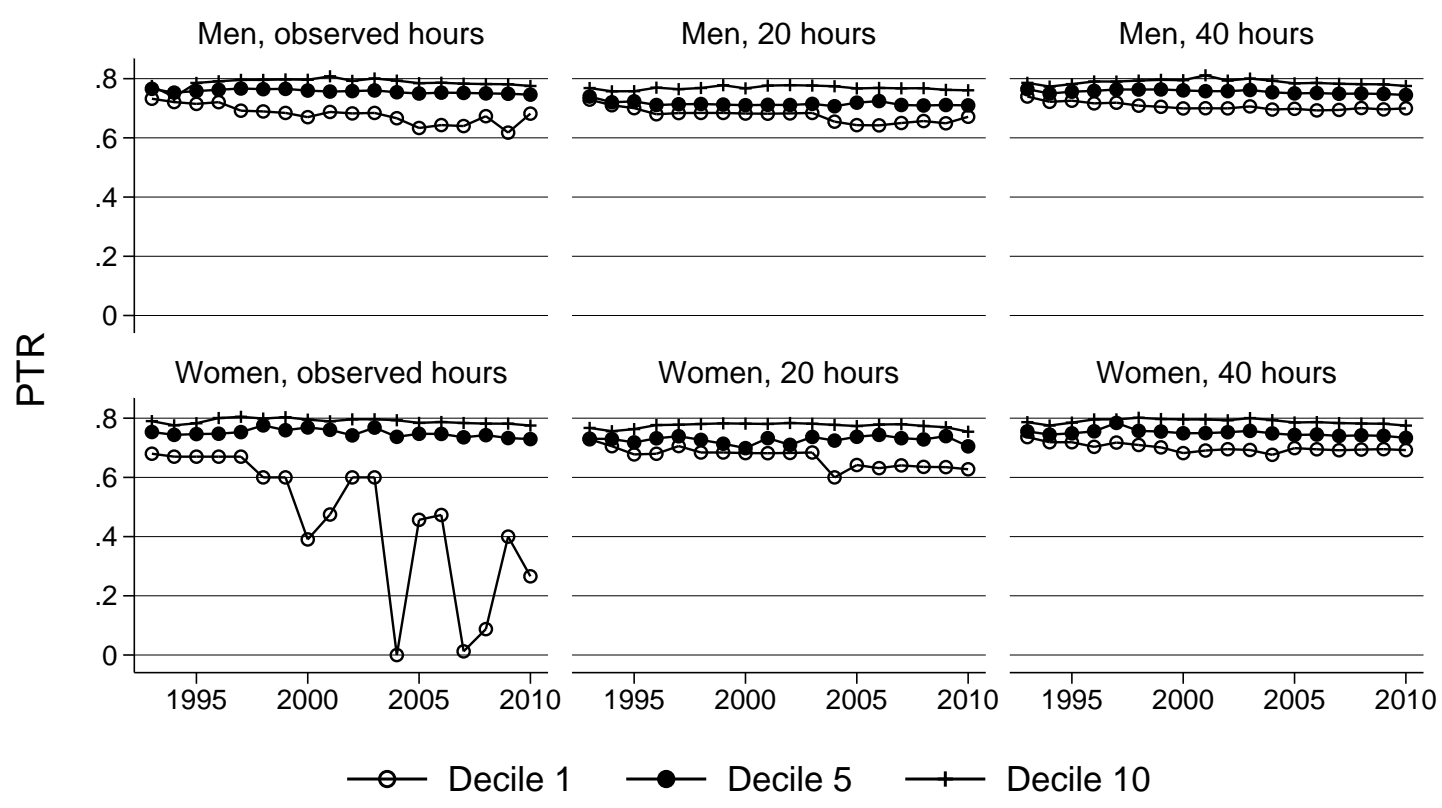

Source: SOEPv29 \& IZA MOD, own calculations.

Figure 4

PTR (short): Distribution by earnings deciles evaluated at observed hours

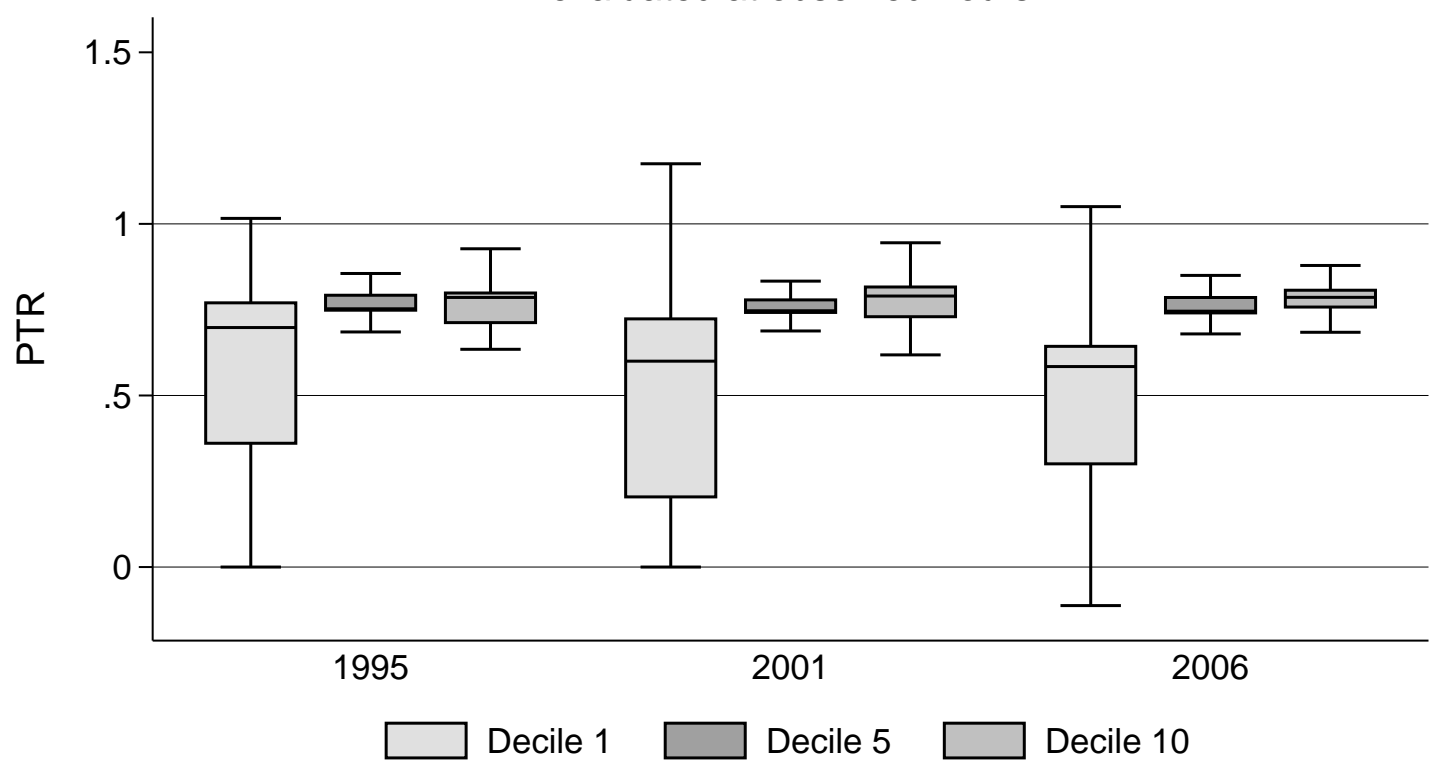

Source: SOEPv29 \& IZA MOD, own calculations. 
Women's PTRs are more dispersed than males' which reflects the greater variety of living arrangements of women. Figure 5 gives the PTR distribution by gender over time. While men are mostly sole or primary earners, women are sole, primary and, most importantly, secondary earners. We will discuss PTRs by household earner type in Section 4.4 .

Figure 5

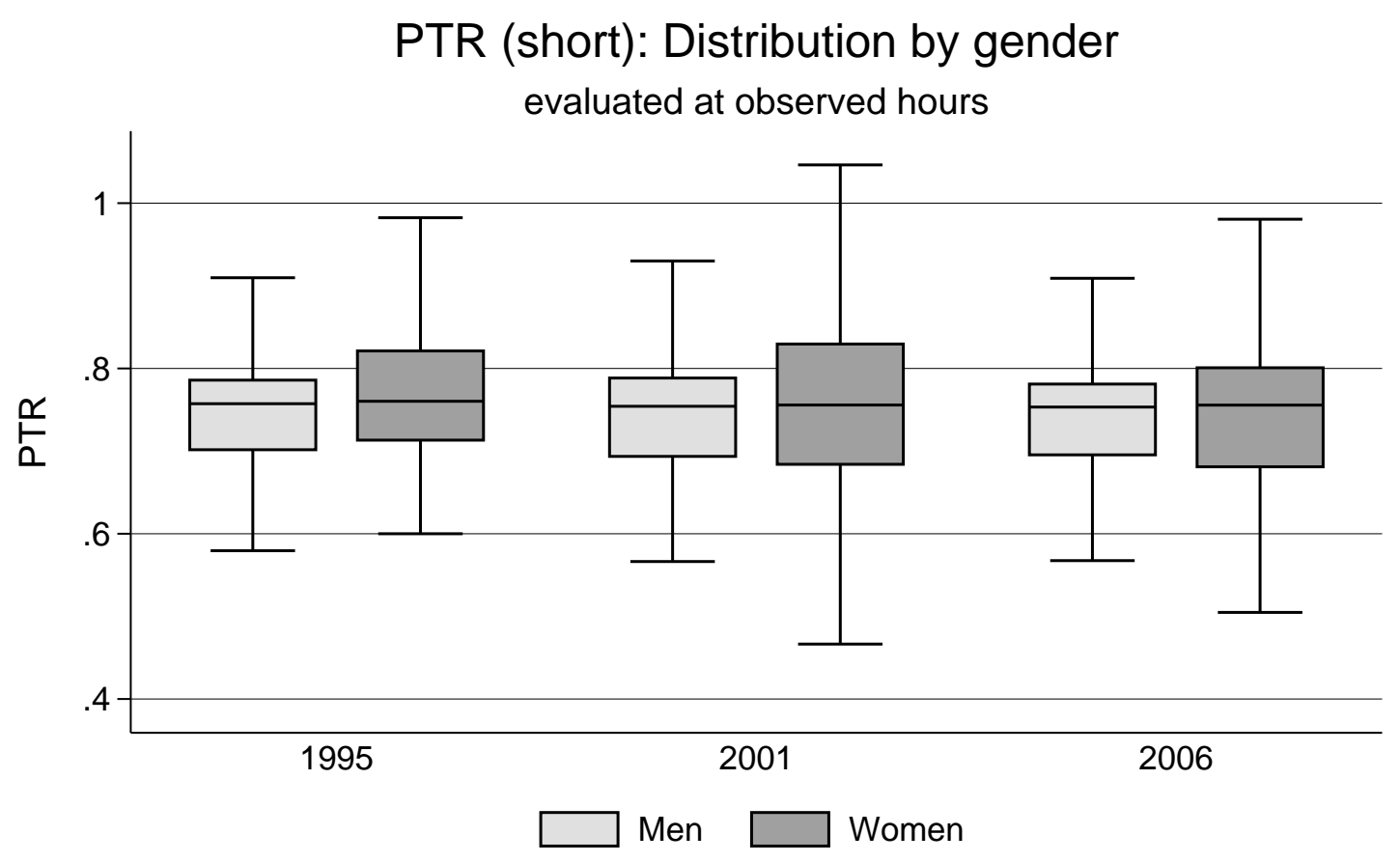

Source: SOEPv29 \& IZA MOD, own calculations.

Younger individuals aged 25-34 tend to face lower PTRs than older age groups as presented by Figure 6. A shorter employment history induces young individuals to be less eligible for unemployment benefits. PTRs decreased for all age groups. 


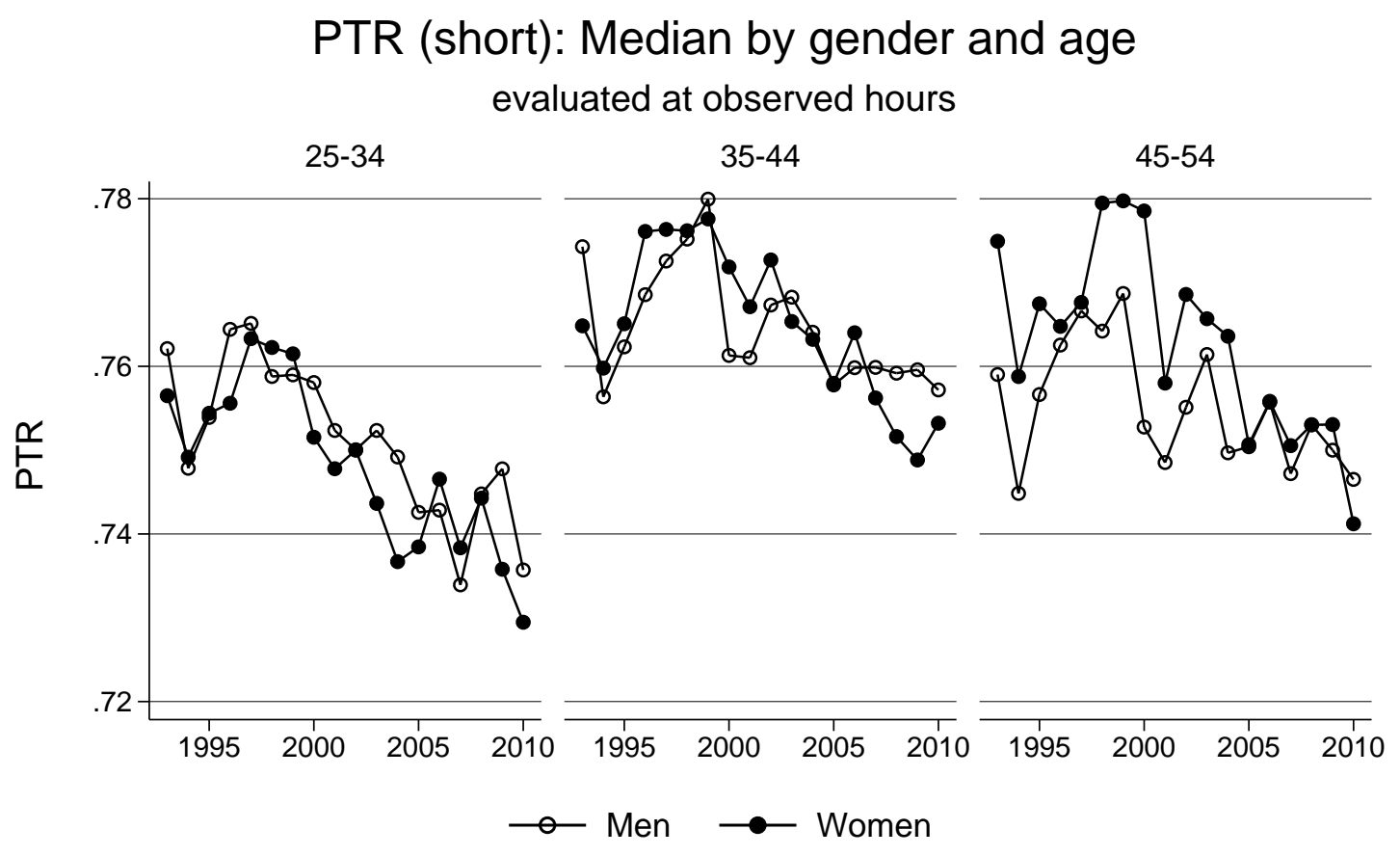

Source: SOEPv29 \& IZA MOD, own calculations.

\subsection{Long-term Participation Tax Rates by Earnings Decile}

The distribution of short- and long-term PTRs by earnings decile is displayed in Figure 7. Long-term PTRs are markedly lower than short-term PTRs. The highest earnings decile reveals a long-term PTR of about $65 \%$ opposed to a short-term PTR of about $80 \%$. The median long-term PTR in the bottom decile fluctuates around $50 \%$ opposed to a short-term PTR higher than $60 \%$. The fall of PTRs when extending the measurement period is due to the decline of income support after one year of unemployment. Hence, standard measures based on annual concepts overestimate the disincentives created by the German tax-benefit system.

The reforms reduced the variation in long-term PTRs for middle and high income earners who cannot claim unemployment assistance anymore after the exhaustion of unemployment benefits. In contrast, there is no clear trend for reduced variation of short-term PTRs.

Median long-term PTRs shift downwards in the post-reform period for both high- and low-income earner as can be taken from Figure 8. Because of the abolition 
Figure 7

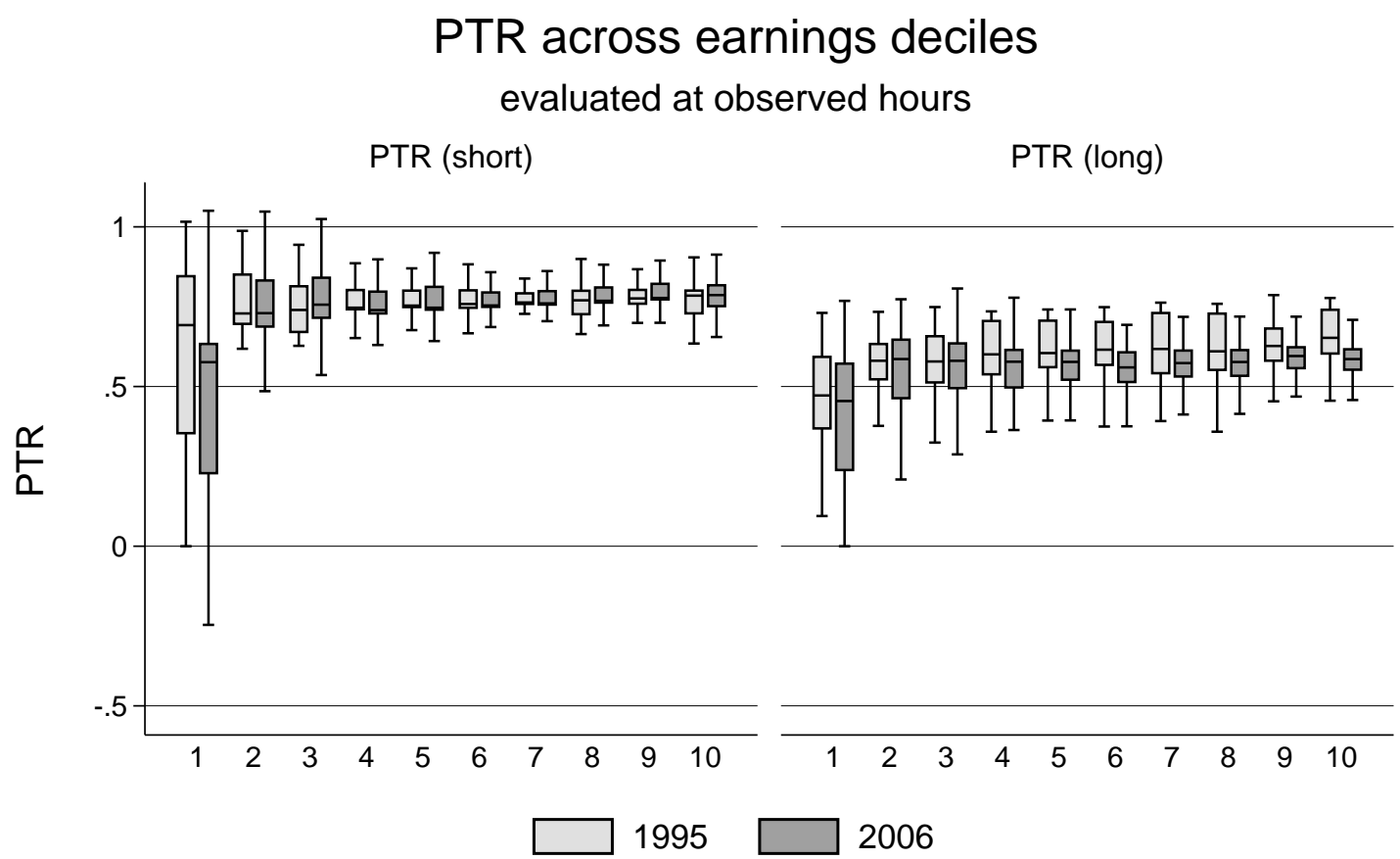

Source: SOEPv29 \& IZA MOD, own calculations.

of unemployment assistance in 2005 income may drop even further to levels of social assistance if the individual is the household's principal earner. Accordingly, the post-reform spread between short-term and long-term PTRs increases to almost 20 percentage points for most deciles. As for short-term PTRs, observed median PTR of women falls the most over the reform period from $40-50 \%$ to about $30 \%$.

The drop of long-term PTRs is even more distinct for median PTRs by gender and age as presented in Figure 9. Particularly for the young, the median PTR drops from about $65 \%$ to about $55 \%$. 
Figure 8

PTR (long): Median by earnings deciles
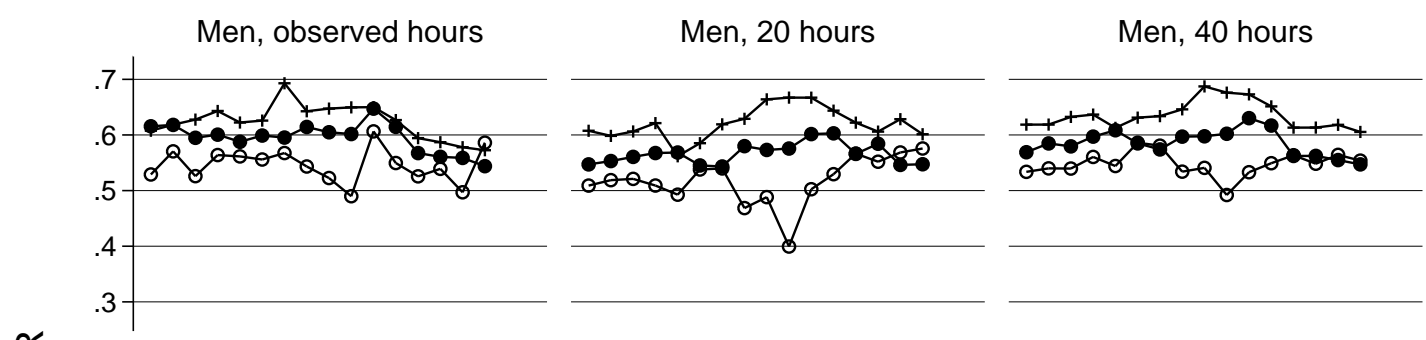

$\stackrel{\Upsilon}{\leftarrow}$

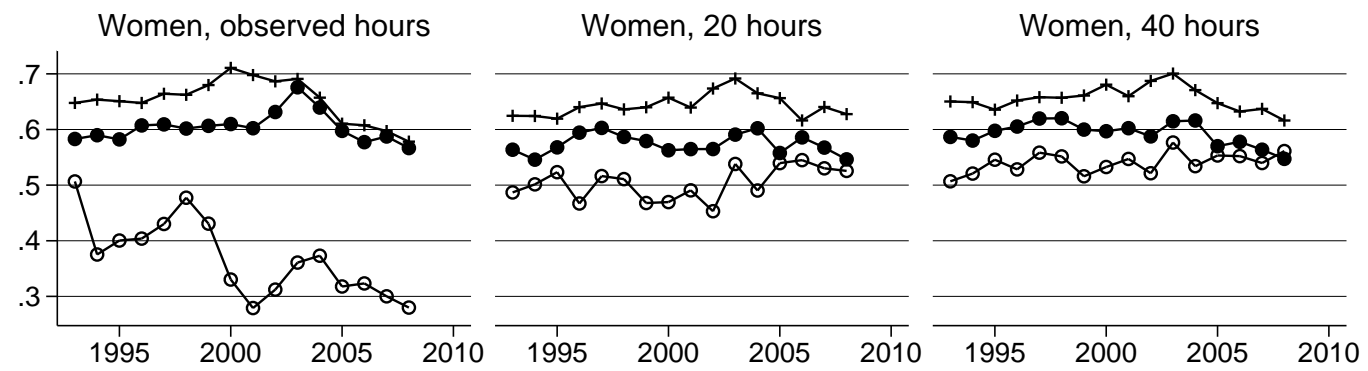

$\multimap$ Decile $1 \multimap$ Decile $5 \multimap$ Decile 10

Source: SOEPv29 \& IZA MOD, own calculations.

Figure 9

PTR (long): Median by gender and age

evaluated at observed hours

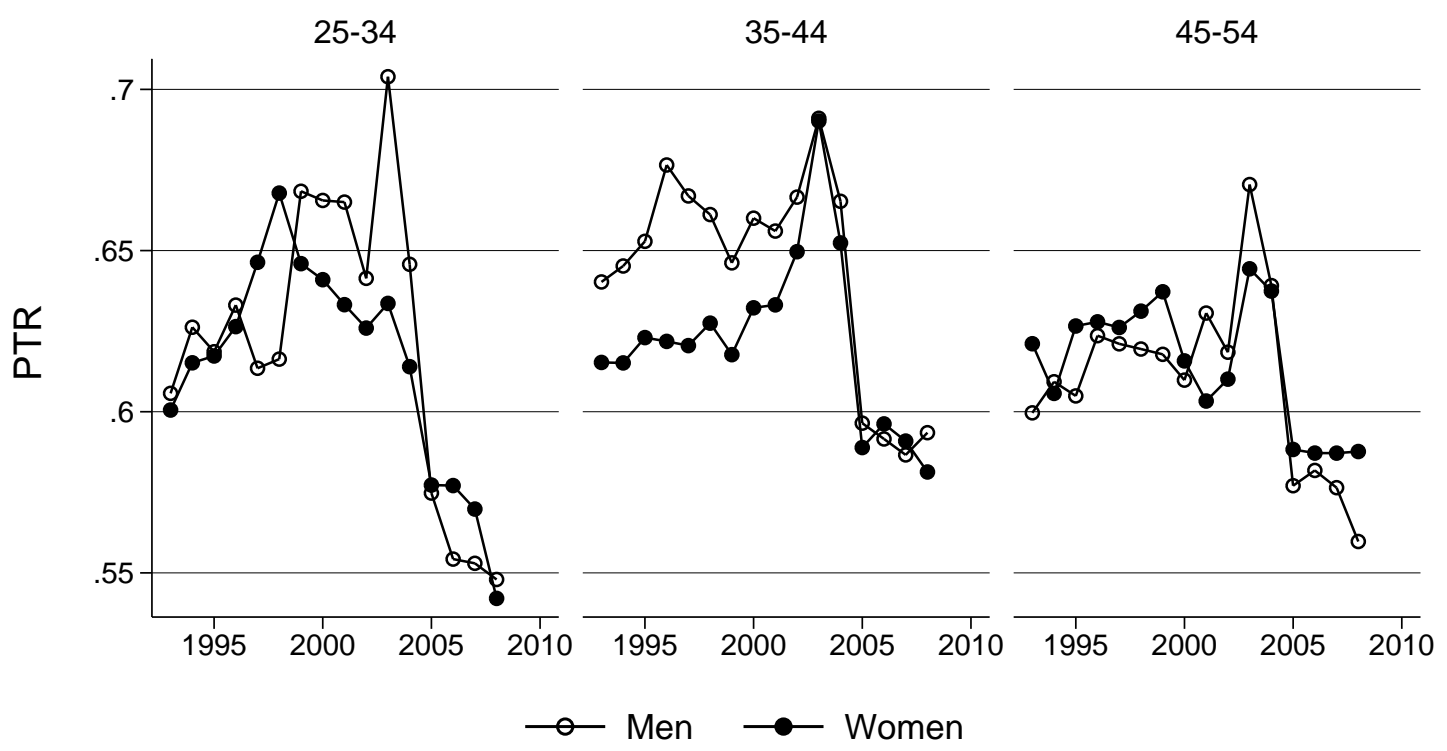

Source: SOEPv29 \& IZA MOD, own calculations. 
Figure 10

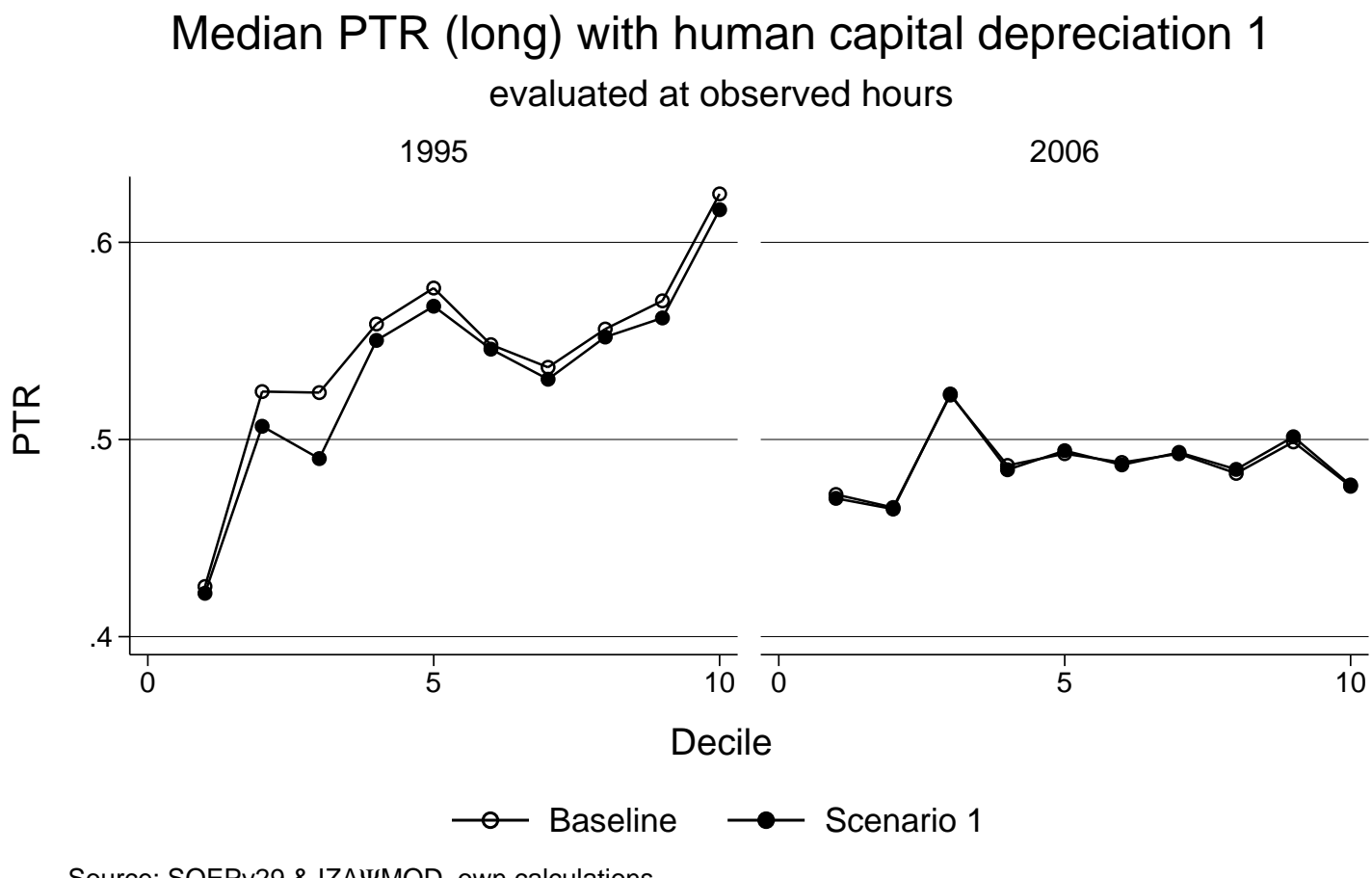

\subsection{Participation Tax Rates with Human Capital Depreci- ation by Earnings Decile}

PTRs by earnings decile accounting for human capital depreciation is presented in Figures 10 and 11. PTRs of scenario 1 in Figure 10 are compared to the sum of the second and third component of a three-year PTR. PTRs of scenario 2 in Figure 11 are compared to the third component of a three-year PTR. Including human capital depreciation decreases the PTR in both scenarios compared to the baseline scenario.

PTRs based on the human capital depreciation scenarios are lower because taxes on depreciated earnings are lower and benefit eligibility after a period of unemployment is reduced. Lost eligibility for unemployment benefits and unemployment assistance explains most of the distance between the baseline scenario and human capital depreciation scenarios before the reforms. The abolishment of unemployment assistance makes the difference in 2006 almost negligible. 
Figure 11

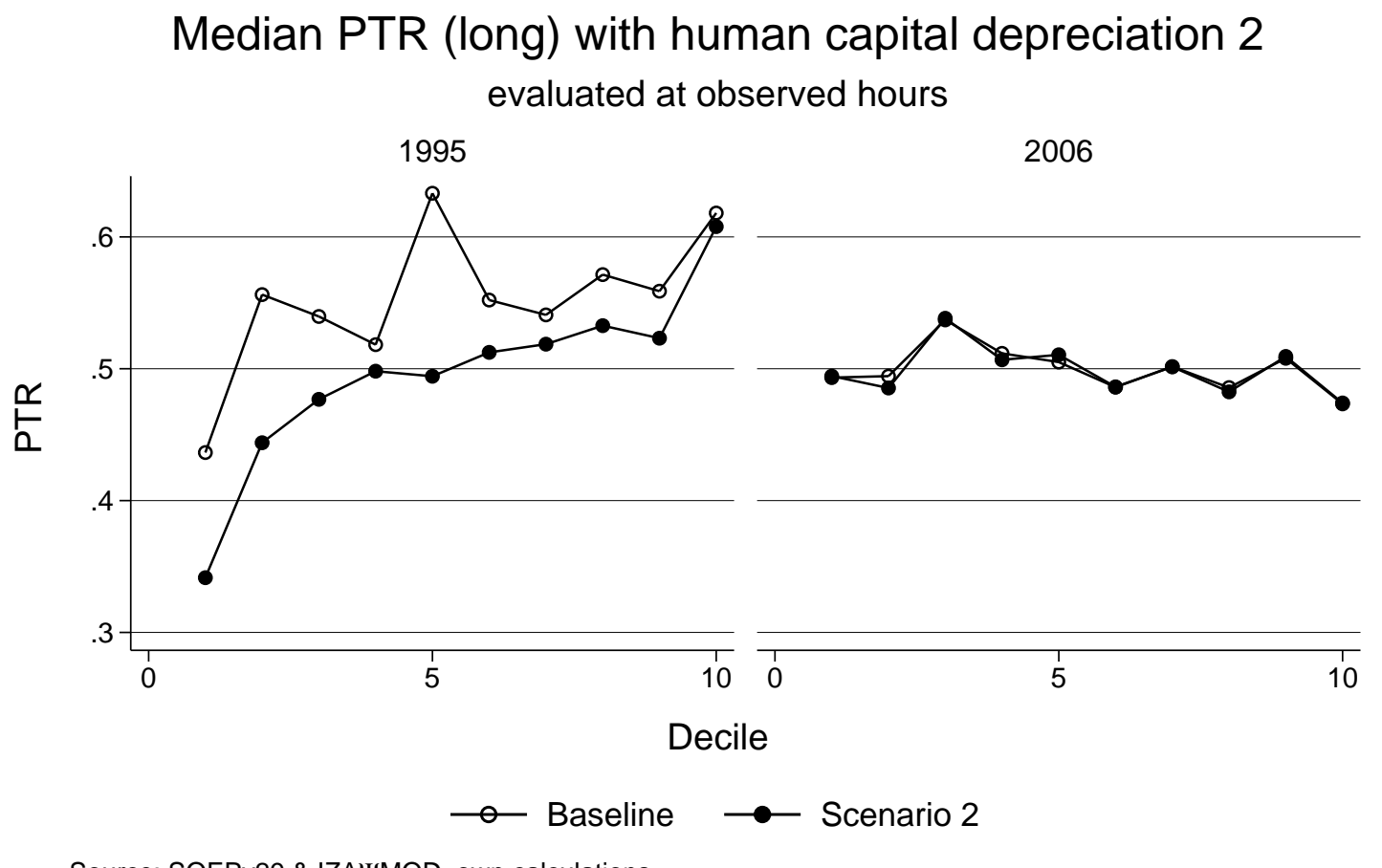

Source: SOEPv29 \& IZA MOD, own calculations.

\subsection{Participation Tax Rates by Household Type}

A PTR highly depends on the household context which determines income taxes paid and transfers received. Figure 12 illustrates how short-term PTRs vary by a household's composition of earners. PTRs are highest for two-earner households. Primary earners face a short-term PTR of about $77 \%$ and secondary earners a shortterm PTR of about $84 \%$. Sole earners benefit most from joint taxation being able to reassert the full splitting advantage and have a PTR of about 70\%. Singles' PTRs of about $75 \%$ lie between those of two-earner households and sole-earner households. The group of secondary earners is very heterogenous with some earning only slightly less than the primary earner and others only marginally employed. As a result, PTRs of secondary earners are more dispersed.

To further investigate the driving forces behind the resulting PTRs, we can break down its components as follows

$$
P T R_{i h}=\frac{\left(t_{h}^{E, i n c}+s_{h}^{E}-b_{h}^{E}\right)-\left(t_{h}^{U, i n c}+s_{h}^{U}-b_{h}^{U}\right)}{y_{i}^{E, w}},
$$




\section{PTR (short): Distribution by earner type evaluated at observed hours}

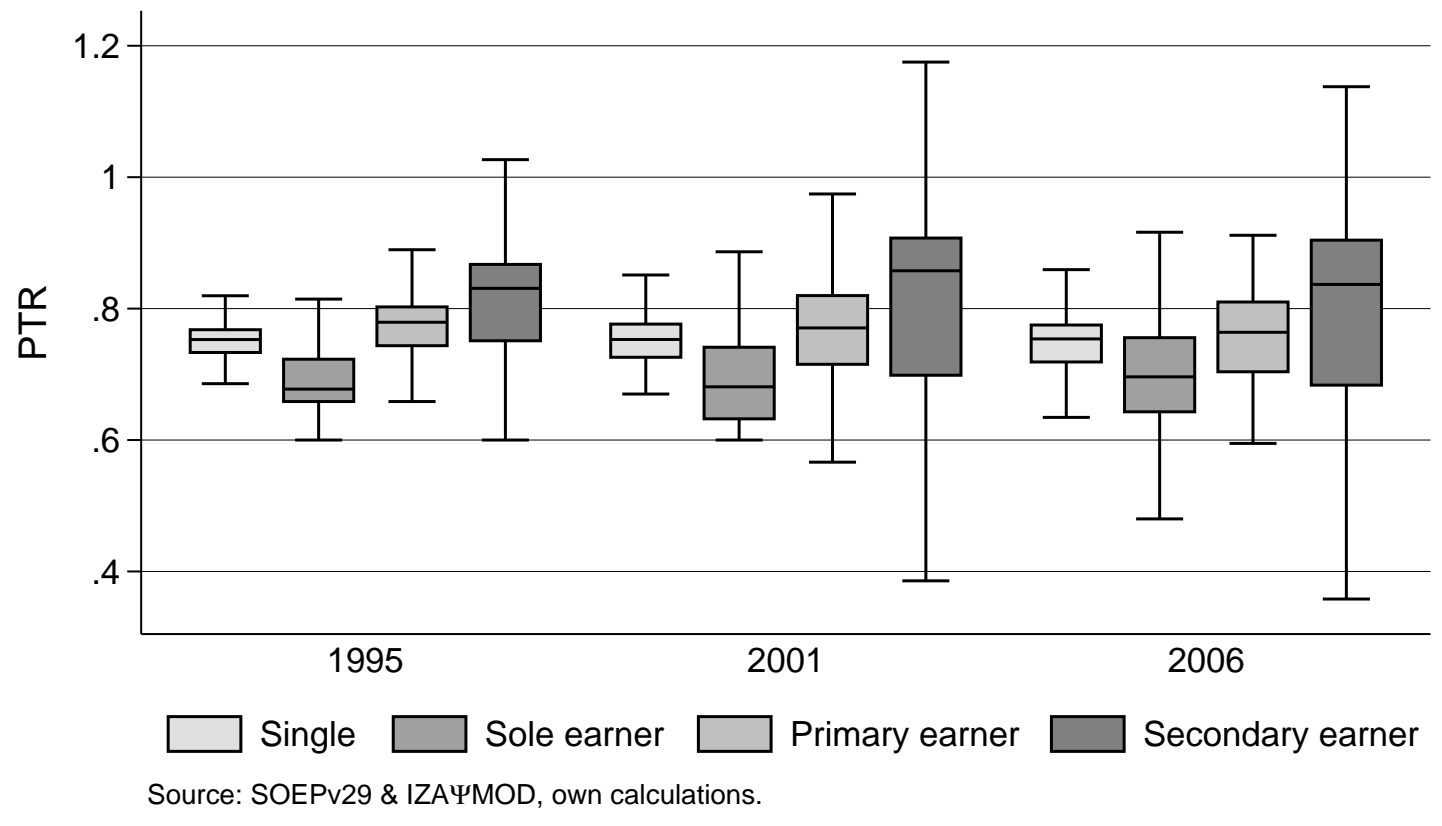

where income taxes are $t_{h}^{i n c}$, social security contributions are $s_{h}$ and benefits are $b_{h}$ in labor market states $E$ and $U$, respectively. Figure 13 gives the median share of each component by household earner type in pre-reform year 1995 and post-reform year 2006 .

The income tax wedge between $E$ and $U$ dropped from $22 \%$ in 1995 to $17 \%$ in 2006 on average. Consequently, the fraction of the PTR attributable to income taxes falls disproportionately. Both singles and sole earners only pay income tax when employed. Their median income tax share $t_{h}^{E, i n c} / y_{i}^{E, w}$ dropped from $18 \%$ to $16 \%$ for singles and from $11 \%$ to $7 \%$ for sole earners who benefit from joint taxation with a spouse with zero earnings. In contrast, individuals in two-earner households face higher income tax wedges paying taxes in both labor market states. The median income tax wedge $\left(t_{h}^{E, \text { inc }}-t_{h}^{U, \text { inc }}\right) / y_{i}^{E, w}$ declines from $45 \%-22 \%=23 \%$ in 1995 to $40 \%-21 \%=19 \%$ in 2006 for secondary earners. The basic tax allowance was raised substantially in the time between such that half of all primary earners are not subject to income taxes in $U$ in the post-reform period the median income tax wedge drops from $26 \%-1 \%=25 \%$ in 1995 to $20 \%-0 \%=20 \%$ in 2006 . 
The share of out-of-work benefits $b_{h}^{U} / y_{i}^{E, w}$ decreased on average from $41 \%$ to $39 \%$. It declines most strongly for secondary earners from $46 \%$ to $43 \%$, whereas all other groups lost only one percentage point. Individuals living in two-earner households are subject to the withdrawal of means-tested benefits when household income exceeds the hypothetical claims. According to the lower level of state support their PTRs should be lower than for singles which is the case for the UK demonstrated by Brewer et al. (2008). However, PTRs in Germany are mainly determined by earnings-related unemployment benefits that do not depend on other household income sources. Additionally, joint taxation creates low income tax shares for sole earners and higher income tax shares for two-earner households. Secondary earners have particularly high shares of out-of-work benefits since the share of unemployment benefits in gross earnings is higher than for other household earner types. Unemployment benefits are $60 \%$ of previous net earnings for childless persons and $67 \%$ for parents, where net earnings are gross earnings reduced by income tax on the respective earnings abstracting from other income sources and social security contributions. The respective average income tax is lower for low-income earners in a progressive income tax system as in Germany. As a result, the share of unemployment benefits in gross earnings is higher for low-income secondary earners.

In sum, we have identified three main drivers of PTRs in Germany. Eligibility for unemployment benefits, which is amongst others determined by the social security earnings threshold, is the most important institutional factor behind a high PTR. The number of earners in the household mainly determines the tax wedge between $E$ and $U$ because of the extent to which joint taxation reduces the household's tax burden in both states. Age and earnings potential seem to be the most relevant individual characteristics determining the size of the PTR. 
Figure 13

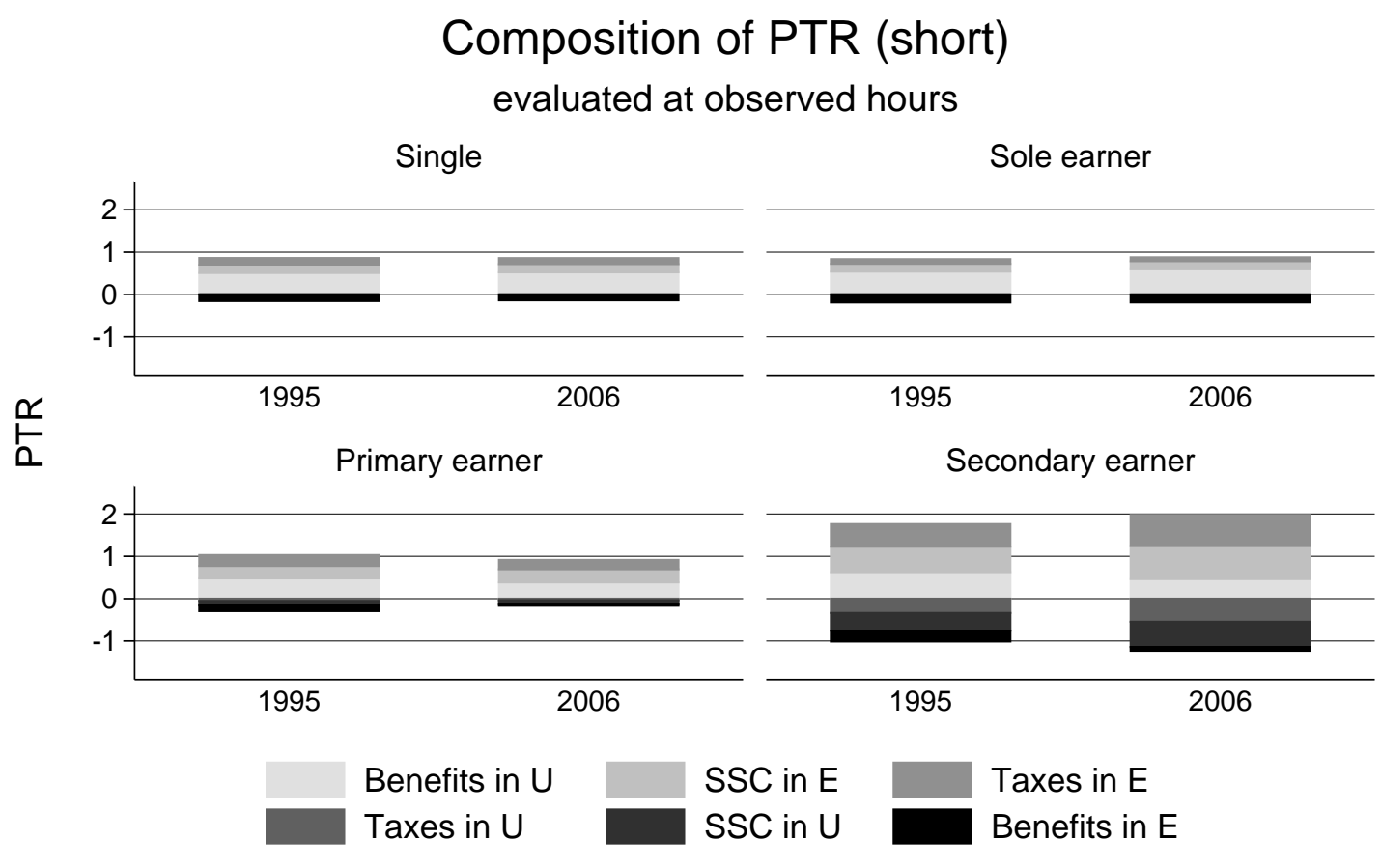

Source: SOEPv29 \& IZA MOD, own calculations.

\section{$5 \quad$ Regression Analysis}

Labor market participation in Germany increased substantially during and after the Hartz reforms at the beginning of the 2000s ${ }^{10}$ These reforms also triggered a reduction in PTRs, i.e., increased work incentives. We thus examine in the following how strongly changes in the PTRs were related to changes in individuals' employment status.

\subsection{Estimation Strategy}

We test in our regression analysis to which extent lower PTRs are associated with an increased likelihood of taking up work. The binary outcome variable is one if individual $i$ switches from non-participation in period $t-1\left(U_{i t-1}\right)$ to participation in period $t\left(E_{i t}\right)$. The main explanatory variable of interest is the PTR-change between period $t-1$ and $t$, i.e., $\triangle P T R_{i t}=P T R_{i t}-P T R_{i t-1}$. We estimate the following

\footnotetext{
${ }^{10}$ See Appendix Figure B.2 for labor market participation in Germany from 1991 to 2012 by gender and age group.
} 
regression model:

$$
P\left(U_{i t-1} \rightarrow E_{i t}\right)=\gamma \Delta P T R_{i t}+X_{i t}^{\prime} \beta+\alpha_{i}+\mu_{t}+\epsilon_{i t}
$$

The coefficient $\gamma$ captures the effect of a PTR-change on the likelihood of taking up work and is expected to be negative, i.e., a decrease (increase) is associated with a higher (lower) likelihood of labor market participation. Controls are captured by $X_{i t}$ and include age, household type, region and state-specific unemployment rates. Year fixed effects capture business cycle fluctuations affecting labor demand and are denoted by $\mu_{t}$. The error term is denoted by $\epsilon_{i t}$. We estimate this equation with ordinary least squares (OLS) and in an individual fixed effects (FE) framework exploiting individual variation around an individual time-invariant fixed effect denoted by $\alpha_{i}$, which captures unobserved heterogeneity, such as preferences for leisure or innate ability affecting the employment status. In addition, we include interactions of the change in PTR with age groups and the unemployment rate in order to test for heterogeneous effects for younger and older workers and whether the incentive effect from the PTR is affected by regional labor market conditions. All estimations are conducted separately for men and women.

A transition from $U$ to $E$ is only observed in the sample if we include those in $U$ as well. Hence, we make use of the simulated earnings for 20 and 40 hours of work for all individuals in the work force independent of their observed labor market status. For the regression analysis, we use PTRs obtained on the basis of these simulated earnings. As discussed in Section 4, we obtain rather similar PTRs with all three simulation scenarios, but slightly overestimate PTRs at the bottom of the earnings distribution when using simulated earnings because of the fixed hours (20 or 40) assumption. In sum, we apply four PTR concepts as independent variable: short- and long-term PTRs each evaluated at 20 or 40 weekly working hours.

\subsection{Estimation Results}

Regression results are presented in Tables 1 4 . The results for the effect of shortterm PTRs are displayed in Tables 1 and 2. Overall, we find that a reduction in the 
PTR has a positive and statistically significant effect on the likelihood of taking up a job with stronger effects for women. This coincides with the empirical result that women are more responsive at the extensive margin than men. The individual fixed effects model obtains bigger effects as can be taken from a comparison of the OLS results in columns (1) for men and (3) for women with the individual fixed effects results in columns (2) and (4), respectively ${ }^{11}$ This suggests that unobserved and time-invariant determinants such as different taste for work or leisure exist and OLS results suffer from heterogeneity bias.

The impact of the short-term PTR on the probability to take up work is also economically significant. E.g., reducing the PTR by ten percentage points increases the probability of taking up work by $0.6-0.9(1.3-1.5)$ percentage points for men (women) depending on whether the PTR is evaluated at 20 or 40 hours per week, respectively. Given the baseline probabilities about three (four) percent for men (women) shown in Figure 1 this is quite substantial in magnitude. It means that policy reforms aiming at increasing work incentives have a sizable impact on employment. Considering heterogeneity across age, we do not find that this result varies significantly across age groups. The only slight exception is found for women where the effect of a change in the short-term PTR is somewhat less pronounced for women of older age compared to the youngest age group between 25 and 34 . The estimates of the interaction terms are however only marginally significant if at all.

The results for the effect of long-term PTRs are displayed in Tables 3 and 4. In general, we find that reductions in the long-term PTR also have a positive impact on the job-take-up probability. The results are slightly smaller in magnitude, by and large around -0.1 for both men and women, which again implies a one percentage point increase in switching to employment for a ten percentage point reduction in the PTR. The results for long-term PTRs are however less precisely estimated and even turn statistically insignificant at conventional levels when being evaluated at 40 hours. The sample size for the estimation of the effect of long-term PTRs is substantially reduced since we have to rely on individuals who are surveyed for at

\footnotetext{
${ }^{11}$ We also estimated the regression model using a logit specification with and without individual fixed effects. The results are qualitatively very similar to the results from the linear probability model. The results are presented in Tables C.1 C.4 in the Appendix.
} 
least three subsequent waves. As a robustness check, we estimate the effect of shortterm PTRs based on the same subsample as used for the long-term PTR's effect. We find that the results do not change, which means that sample selection bias is not an issue here.

Table 1: Effect of short-term PTR on participation (evaluated at 20 hours)

\begin{tabular}{|c|c|c|c|c|}
\hline & \multicolumn{2}{|c|}{ Men } & \multicolumn{2}{|c|}{ Women } \\
\hline & $\begin{array}{l}\text { OLS } \\
(1)\end{array}$ & $\begin{array}{l}\mathrm{FE} \\
(2)\end{array}$ & $\begin{array}{l}\text { OLS } \\
(3)\end{array}$ & $\begin{array}{l}\mathrm{FE} \\
(4)\end{array}$ \\
\hline$\Delta$ PTR (short) & $\begin{array}{l}-0.033 \\
(0.101)\end{array}$ & $\begin{array}{c}-0.062^{* *} \\
(0.015)\end{array}$ & $\begin{array}{c}-0.088^{* * *} \\
(0.000)\end{array}$ & $\begin{array}{c}-0.132^{* * *} \\
(0.000)\end{array}$ \\
\hline$\Delta$ PTR $($ short $) \times($ age $35-44)$ & $\begin{array}{c}0.024 \\
(0.432)\end{array}$ & $\begin{array}{c}0.015 \\
(0.695)\end{array}$ & $\begin{array}{c}0.042 \\
(0.157)\end{array}$ & $\begin{array}{l}0.058^{*} \\
(0.098)\end{array}$ \\
\hline$\Delta \operatorname{PTR}($ short $) \times($ age $45-54)$ & $\begin{array}{l}-0.002 \\
(0.933)\end{array}$ & $\begin{array}{l}-0.006 \\
(0.872)\end{array}$ & $\begin{array}{c}0.038 \\
(0.229)\end{array}$ & $\begin{array}{c}0.058 \\
(0.115)\end{array}$ \\
\hline$\Delta$ PTR (short) $\times \Delta$ U-rate & $\begin{array}{c}0.012 \\
(0.226)\end{array}$ & $\begin{array}{c}0.015 \\
(0.250)\end{array}$ & $\begin{array}{c}0.001 \\
(0.940)\end{array}$ & $\begin{array}{l}-0.006 \\
(0.606)\end{array}$ \\
\hline age $35-44$ & $\begin{array}{c}-0.018^{* * *} \\
(0.000)\end{array}$ & $\begin{array}{c}0.002 \\
(0.776)\end{array}$ & $\begin{array}{c}-0.026^{* * *} \\
(0.000)\end{array}$ & $\begin{array}{c}-0.020^{* *} \\
(0.012)\end{array}$ \\
\hline age $45-54$ & $\begin{array}{c}-0.023^{* * *} \\
(0.000)\end{array}$ & $\begin{array}{c}0.016 \\
(0.133)\end{array}$ & $\begin{array}{c}-0.027^{* * *} \\
(0.000)\end{array}$ & $\begin{array}{l}-0.010 \\
(0.396)\end{array}$ \\
\hline$\Delta$ U-rate & $\begin{array}{l}-0.002 \\
(0.265)\end{array}$ & $\begin{array}{l}-0.001 \\
(0.472)\end{array}$ & $\begin{array}{c}-0.010^{* * *} \\
(0.001)\end{array}$ & $\begin{array}{c}-0.011^{* * *} \\
(0.003)\end{array}$ \\
\hline East & $\begin{array}{c}0.011^{* * *} \\
(0.002)\end{array}$ & $\begin{array}{l}-0.010 \\
(0.595)\end{array}$ & $\begin{array}{l}0.007^{*} \\
(0.074)\end{array}$ & $\begin{array}{l}-0.005 \\
(0.880)\end{array}$ \\
\hline Year FE & Yes & Yes & Yes & Yes \\
\hline Household type FE & Yes & Yes & Yes & Yes \\
\hline Skill level FE & Yes & Yes & Yes & Yes \\
\hline Adjusted $R^{2}$ & 0.005 & 0.008 & 0.014 & 0.015 \\
\hline$R^{2}$ (within) & & 0.009 & & 0.016 \\
\hline $\mathrm{N}$ & 23566 & 23566 & 26763 & 26763 \\
\hline
\end{tabular}

Note: P-value indicated in brackets. ${ }^{* * *}=$ significant at the 1 percent level, $* *=$ significant at the 5 percent level, ${ }^{*}=$ significant at the 1 percent level. Household type fixed effects include binary indicators for categories single, single parent, couple (without children) and couple with children. Skill level fixed effects include binary indicators for low, medium and high level of education. 
Table 2: Effect of short-term PTR on participation (evaluated at 40 hours)

\begin{tabular}{|c|c|c|c|c|}
\hline & \multicolumn{2}{|c|}{ Men } & \multicolumn{2}{|c|}{ Women } \\
\hline & $\begin{array}{c}\text { OLS } \\
(1)\end{array}$ & $\begin{array}{l}\mathrm{FE} \\
(2)\end{array}$ & $\begin{array}{c}\text { OLS } \\
(3)\end{array}$ & $\begin{array}{l}\mathrm{FE} \\
(4)\end{array}$ \\
\hline$\Delta$ PTR (short) & $\begin{array}{c}-0.061^{* * *} \\
(0.007)\end{array}$ & $\begin{array}{c}-0.093^{* * *} \\
(0.001)\end{array}$ & $\begin{array}{c}-0.105^{* * *} \\
(0.000)\end{array}$ & $\begin{array}{c}-0.151^{* * *} \\
(0.000)\end{array}$ \\
\hline$\Delta \mathrm{PTR}($ short $) \times($ age $35-44)$ & $\begin{array}{c}0.024 \\
(0.496)\end{array}$ & $\begin{array}{c}0.011 \\
(0.799)\end{array}$ & $\begin{array}{c}0.038 \\
(0.256)\end{array}$ & $\begin{array}{c}0.045 \\
(0.280)\end{array}$ \\
\hline$\Delta \mathrm{PTR}($ short $) \times($ age $45-54)$ & $\begin{array}{c}0.004 \\
(0.903)\end{array}$ & $\begin{array}{l}-0.005 \\
(0.909)\end{array}$ & $\begin{array}{c}0.047 \\
(0.187)\end{array}$ & $\begin{array}{c}0.067 \\
(0.119)\end{array}$ \\
\hline$\Delta \mathrm{PTR}$ (short) $\times \Delta$ U-rate & $\begin{array}{c}0.015 \\
(0.193)\end{array}$ & $\begin{array}{c}0.019 \\
(0.191)\end{array}$ & $\begin{array}{c}0.002 \\
(0.797)\end{array}$ & $\begin{array}{l}-0.006 \\
(0.639)\end{array}$ \\
\hline age $35-44$ & $\begin{array}{c}-0.019^{* * *} \\
(0.000)\end{array}$ & $\begin{array}{c}0.002 \\
(0.772)\end{array}$ & $\begin{array}{c}-0.025^{* * *} \\
(0.000)\end{array}$ & $\begin{array}{c}-0.020^{* *} \\
(0.014)\end{array}$ \\
\hline age $45-54$ & $\begin{array}{c}-0.023^{* * *} \\
(0.000)\end{array}$ & $\begin{array}{c}0.016 \\
(0.140)\end{array}$ & $\begin{array}{c}-0.027^{* * *} \\
(0.000)\end{array}$ & $\begin{array}{l}-0.010 \\
(0.392)\end{array}$ \\
\hline$\Delta$ U-rate & $\begin{array}{l}-0.002 \\
(0.271)\end{array}$ & $\begin{array}{l}-0.001 \\
(0.500)\end{array}$ & $\begin{array}{c}-0.010^{* * *} \\
(0.001)\end{array}$ & $\begin{array}{c}-0.010^{* * *} \\
(0.005)\end{array}$ \\
\hline East & $\begin{array}{c}0.011^{* * *} \\
(0.003)\end{array}$ & $\begin{array}{l}-0.012 \\
(0.526)\end{array}$ & $\begin{array}{l}0.008^{*} \\
(0.067)\end{array}$ & $\begin{array}{l}-0.006 \\
(0.857)\end{array}$ \\
\hline Year FE & Yes & Yes & Yes & Yes \\
\hline Household type FE & Yes & Yes & Yes & Yes \\
\hline Skill level FE & Yes & Yes & Yes & Yes \\
\hline Adjusted $R^{2}$ & 0.006 & 0.010 & 0.014 & 0.016 \\
\hline$R^{2}$ (within) & & 0.012 & & 0.017 \\
\hline $\mathrm{N}$ & 23566 & 23566 & 26763 & 26763 \\
\hline
\end{tabular}

Note: $\mathrm{P}$-value indicated in brackets. $* * *=$ significant at the 1 percent level, $* *=$ significant at the 5 percent level, ${ }^{*}=$ significant at the 1 percent level. Household type fixed effects include binary indicators for categories single, single parent, couple (without children) and couple with children. Skill level fixed effects include binary indicators for low, medium and high level of education. 
Table 3: Effect of long-term PTR on participation (evaluated at 20 hours)

\begin{tabular}{|c|c|c|c|c|}
\hline & \multicolumn{2}{|c|}{ Men } & \multicolumn{2}{|c|}{ Women } \\
\hline & $\begin{array}{l}\text { OLS } \\
(1)\end{array}$ & $\begin{array}{l}\mathrm{FE} \\
(2)\end{array}$ & $\begin{array}{c}\text { OLS } \\
(3)\end{array}$ & $\begin{array}{l}\mathrm{FE} \\
(4)\end{array}$ \\
\hline$\Delta$ PTR (long) & $\begin{array}{l}0.081^{*} \\
(0.083)\end{array}$ & $\begin{array}{l}-0.098^{*} \\
(0.053)\end{array}$ & $\begin{array}{l}-0.071^{*} \\
(0.074)\end{array}$ & $\begin{array}{c}-0.099^{* *} \\
(0.040)\end{array}$ \\
\hline$\Delta$ PTR $($ long $) \times($ age $35-44)$ & $\begin{array}{l}-0.028 \\
(0.704)\end{array}$ & $\begin{array}{c}0.044 \\
(0.575)\end{array}$ & $\begin{array}{l}0.147^{* *} \\
(0.014)\end{array}$ & $\begin{array}{c}0.075 \\
(0.235)\end{array}$ \\
\hline$\Delta \mathrm{PTR}($ long $) \times($ age $45-54)$ & $\begin{array}{c}0.050 \\
(0.422)\end{array}$ & $\begin{array}{l}0.124^{* *} \\
(0.050)\end{array}$ & $\begin{array}{c}0.008 \\
(0.894)\end{array}$ & $\begin{array}{l}-0.037 \\
(0.662)\end{array}$ \\
\hline$\Delta$ PTR (long) $\times \Delta$ U-rate & $\begin{array}{c}0.010 \\
(0.641)\end{array}$ & $\begin{array}{c}0.006 \\
(0.794)\end{array}$ & $\begin{array}{c}0.001 \\
(0.990)\end{array}$ & $\begin{array}{l}-0.049 \\
(0.287)\end{array}$ \\
\hline age $35-44$ & $\begin{array}{l}-0.011^{*} \\
(0.051)\end{array}$ & $\begin{array}{c}0.022^{* *} \\
(0.025)\end{array}$ & $\begin{array}{c}-0.019^{* * *} \\
(0.001)\end{array}$ & $\begin{array}{c}-0.017^{*} \\
(0.094)\end{array}$ \\
\hline age $45-54$ & $\begin{array}{c}-0.019^{* * *} \\
(0.000)\end{array}$ & $\begin{array}{c}0.054^{* * *} \\
(0.004)\end{array}$ & $\begin{array}{c}-0.016^{* * *} \\
(0.008)\end{array}$ & $\begin{array}{l}-0.012 \\
(0.482)\end{array}$ \\
\hline$\Delta$ U-rate & $\begin{array}{c}0.002 \\
(0.372)\end{array}$ & $\begin{array}{c}0.003 \\
(0.266)\end{array}$ & $\begin{array}{c}-0.016^{* *} \\
(0.015)\end{array}$ & $\begin{array}{c}-0.015^{*} \\
(0.054)\end{array}$ \\
\hline East & $\begin{array}{l}0.015^{* *} \\
(0.010)\end{array}$ & $\begin{array}{l}-0.021 \\
(0.165)\end{array}$ & $\begin{array}{l}0.015^{* *} \\
(0.013)\end{array}$ & $\begin{array}{l}-0.014 \\
(0.699)\end{array}$ \\
\hline Year FE & Yes & Yes & Yes & Yes \\
\hline Household type FE & Yes & Yes & Yes & Yes \\
\hline Skill level FE & Yes & Yes & Yes & Yes \\
\hline Adjusted $R^{2}$ & 0.009 & 0.014 & 0.015 & 0.018 \\
\hline $\begin{array}{l}R^{2} \text { (within) } \\
\mathrm{N}\end{array}$ & 10625 & $\begin{array}{l}0.016 \\
10625\end{array}$ & 12053 & $\begin{array}{l}0.020 \\
12053\end{array}$ \\
\hline
\end{tabular}

Note: $\mathrm{P}$-value indicated in brackets. $* * *=$ significant at the 1 percent level, $* *=$ significant at the 5 percent level, ${ }^{*}=$ significant at the 1 percent level. Household type fixed effects include binary indicators for categories single, single parent, couple (without children) and couple with children. Skill level fixed effects include binary indicators for low, medium and high level of education. 
Table 4: Effect of long-term PTR on participation (evaluated at 40 hours)

\begin{tabular}{|c|c|c|c|c|}
\hline & \multicolumn{2}{|c|}{ Men } & \multicolumn{2}{|c|}{ Women } \\
\hline & $\begin{array}{l}\text { OLS } \\
(1)\end{array}$ & $\begin{array}{l}\mathrm{FE} \\
(2)\end{array}$ & $\begin{array}{c}\text { OLS } \\
(3)\end{array}$ & $\begin{array}{l}\mathrm{FE} \\
(4)\end{array}$ \\
\hline$\Delta$ PTR (long) & $\begin{array}{l}0.127^{* *} \\
(0.022)\end{array}$ & $\begin{array}{l}-0.086 \\
(0.127)\end{array}$ & $\begin{array}{l}-0.071 \\
(0.182)\end{array}$ & $\begin{array}{l}-0.105 \\
(0.106)\end{array}$ \\
\hline$\Delta$ PTR $($ long $) \times($ age $35-44)$ & $\begin{array}{l}-0.017 \\
(0.855)\end{array}$ & $\begin{array}{c}0.041 \\
(0.673)\end{array}$ & $\begin{array}{l}0.178^{* *} \\
(0.016)\end{array}$ & $\begin{array}{c}0.077 \\
(0.333)\end{array}$ \\
\hline$\Delta$ PTR $($ long $) \times($ age $45-54)$ & $\begin{array}{c}0.038 \\
(0.594)\end{array}$ & $\begin{array}{c}0.102 \\
(0.155)\end{array}$ & $\begin{array}{c}0.005 \\
(0.942)\end{array}$ & $\begin{array}{l}-0.061 \\
(0.577)\end{array}$ \\
\hline$\Delta \mathrm{PTR}($ long $) \times \Delta$ U-rate & $\begin{array}{c}0.035 \\
(0.172)\end{array}$ & $\begin{array}{c}0.022 \\
(0.535)\end{array}$ & $\begin{array}{c}0.016 \\
(0.728)\end{array}$ & $\begin{array}{l}-0.049 \\
(0.365)\end{array}$ \\
\hline age $35-44$ & $\begin{array}{l}-0.011^{*} \\
(0.052)\end{array}$ & $\begin{array}{l}0.023^{* *} \\
(0.022)\end{array}$ & $\begin{array}{c}-0.018^{* * *} \\
(0.002)\end{array}$ & $\begin{array}{l}-0.017 \\
(0.105)\end{array}$ \\
\hline age $45-54$ & $\begin{array}{c}-0.018^{* * *} \\
(0.001)\end{array}$ & $\begin{array}{c}0.055^{* * *} \\
(0.003)\end{array}$ & $\begin{array}{c}-0.015^{* * *} \\
(0.009)\end{array}$ & $\begin{array}{l}-0.011 \\
(0.494)\end{array}$ \\
\hline$\Delta$ U-rate & $\begin{array}{c}0.002 \\
(0.355)\end{array}$ & $\begin{array}{c}0.003 \\
(0.259)\end{array}$ & $\begin{array}{c}-0.016^{* *} \\
(0.015)\end{array}$ & $\begin{array}{l}-0.015^{*} \\
(0.062)\end{array}$ \\
\hline East & $\begin{array}{l}0.014^{* *} \\
(0.013)\end{array}$ & $\begin{array}{l}-0.021 \\
(0.175)\end{array}$ & $\begin{array}{l}0.015^{* *} \\
(0.014)\end{array}$ & $\begin{array}{l}-0.015 \\
(0.684)\end{array}$ \\
\hline Year FE & Yes & Yes & Yes & Yes \\
\hline Household type FE & Yes & Yes & Yes & Yes \\
\hline Skill level FE & Yes & Yes & Yes & Yes \\
\hline Adjusted $R^{2}$ & 0.010 & 0.013 & 0.015 & 0.017 \\
\hline$R^{2}$ (within) & & 0.016 & & 0.020 \\
\hline $\mathrm{N}$ & 10625 & 10625 & 12053 & 12053 \\
\hline
\end{tabular}

Note: P-value indicated in brackets. ${ }^{* * *}=$ significant at the 1 percent level, $* *=$ significant at the 5 percent level, ${ }^{*}=$ significant at the 1 percent level. Household type fixed effects include binary indicators for categories single, single parent, couple (without children) and couple with children. Skill level fixed effects include binary indicators for low, medium and high level of education. 


\section{Conclusions}

This paper investigates incentives to take up work inherent in the German taxbenefit system measured by Participation Tax Rates (PTR). Based on rich microdata as well as a detailed tax-benefit simulation model for Germany, we provide extensive descriptive evidence for the trends of the PTR over the period 1993-2010 across the entire earnings distribution as well as for population subgroups like gender, age and household earner type. Moreover, we extend the standard definition of the (short-term) PTR to a longer time horizon, taking into account that individuals currently not in employment may have a longer-term perspective on their participation decision.

Our descriptive results show that long-term PTRs are significantly lower than short-term PTRs. Three-year PTRs vary between 50\% and 65\% depending on the earnings level, whereas short-term PTRs based on a one-year period are between $70 \%$ and $80 \%$. Work incentives are higher if the time horizon is extended to more than one year. Hence, standard measures overestimate the disincentives created by the German tax-benefit system.

We have identified three main drivers of PTRs in Germany. Eligibility for unemployment benefits, which is amongst others determined by the social security earnings threshold, is the most important institutional factor behind a high PTR. Low-income earner face particularly low PTRs not being eligible for unemployment benefits. The number of earners in the household mainly determines the tax wedge between $E$ and $U$ because of the extent to which joint taxation reduces the household's tax burden in both states. Age and earnings potential seem to be the most relevant individual characteristics. PTRs are lower for younger age groups and for sole earners who benefit most from joint taxation.

Germany's tax and labor market reforms in the early 2000s substantially reduced PTRs, particularly for low-income earners. Our regression analysis reveals that a PTR reduction indeed increases the likelihood of taking up work significantly, particularly for women. Hence, improved work incentives most likely contributed to the observed increase in labor market participation in the aftermath of the reforms in Germany. Finally, the work incentive measure derived from optimal tax theory 
seems to have empirical relevance for observed labor supply decisions. 


\section{References}

Adam, S., M. Brewer, and A. Shephard (2006). The poverty trade-off. Work incentives and income redistribution in Britain. Policy Press.

Bönke, T. and S. Eichfelder (2010). Horizontal equity in the German tax-benefit system: A simulation approach for employees. FinanzArchiv - Public Finance Analysis 66, 295-331.

Brewer, M., E. Saez, and A. Shephard (2008). Means-testing and tax rates on earnings. Prepared for the Report of a Commission on Reforming the Tax System for the 21st Century, Chared by Sir James Mirrlees, Institute for Fiscal Studies.

Chetty, R., A. Guren, D. Manoli, and A. Weber (2013). Does Indivisible Labor Explain the Difference between Micro and Macro Elasticities? A Meta-Analysis of Extensive Margin Elasticities. NBER Macroeconomics Annual 2012 27, 1-56.

Corneo, G. (2005). Verteilungsarithmetik der rot-grünen Steuerreform. Schmollers Jahrbuch - Journal of Applied Social Science Studies 125, 299-314.

Diamond, P. (1980). Income Taxation with Fixed Hours of Work. Journal of Public Economics 13, 101-110.

Dockery, A., R. Ong, and G. Wood (2011). Welfare Traps in Australia: Do they bite? CLMR Discussion Papier Series No. 08/02.

Gregory, M. and R. Jukes (2001). Unemployment and Subsequent Earnings: Estimating Scarring among British Men 1984-94. The Economic Journal 111, F607F625.

Heckman, J. (1979). Sample Selection Bias as a Specification Error. Econometrica $47,153-161$.

Immervoll, H., H. Kleven, C. Kreiner, and E. Saez (2007). Welfare reform in European countries: a microsimulation analysis. The Economic Journal 117, 1-44.

Immervoll, H., H. Kleven, C. Kreiner, and N. Verdelin (2009). An Evaluation of the Tax-Transfer Treatment of Married Couples in European Countries. IZADiscussion Paper No. 3965.

Jacquet, L., E. Lehmann, and B. V. der Linden (2013). Optimal redistributive taxation with both extensive and intensive responses. Journal of Economic Theory $148,1770-1805$.

Kim, M.-K. and S. Polachek (1994). Panel Estimates of Male-Female Earnings Functions. The Journal of Human Resources 29(2), 406-428.

Löffler, M., A. Peichl, N. Pestel, S. Siegloch, and E. Sommer (2014, October). Documentation IZA $\Psi$ MOD v3.0: The IZA Policy Simulation Model. IZA Discussion Paper Nr. 8553. 
Meghir, C. and D. Phillips (2010). Labor Supply and Taxes, Chapter 3 for Mirrlees Review (2009). In J. Mirrlees, S. Adam, T. Besley, R. Blundell, S. Bond, R. Chote, M. Gammie, P. Johnson, G. Myles, and J. Poterba (Eds.), Dimensions of Tax Design: the Mirrlees Review. Oxford University Press.

Mincer, J. and H. Ofek (1982). Depreciation and Restoration of Human Capital. The Journal of Human Resources 17(1), 3-24.

Mirrlees, J. (1971). An Exploration in the Theory of Optimal Income Taxation. Review of Economic Studies 38, 175-208.

O'Donoghue, C. (2011). Do tax-benefit systems cause high replacement rates? A decompositional analysis using EUROMOD. LABOUR 25, 126-151.

Pirttillä, J. and H. Selin (2011). Tax Policy and Employment: How does the Swedish system fare. CESifo Working Paper Series No. 3355.

Saez, E. (2002). Optimal Income Transfer Programs: Intensive versus Extensive Labor Supply Responses. Quarterly Journal of Economics 117, 1039-1073.

Wagner, G., J. Frick, and J. Schupp (2007). The German Socio-Economic Panel Study (SOEP) - Scope, evolution and enhancements. Schmollers Jahrbuch - Journal of Applied Social Science Studies 127, 139-170. 


\section{Appendix}

\section{A German Tax-Benefit System}

\section{A.1 Benefits}

Statutory provisions for each of the potential transfer payments are described in the following. Individual in state $U$ are potentially eligible for insurance payments and means-tested payments.

\section{A.1.1 Unemployment Benefits}

As an insurance program, a potential receipt of unemployment benefits depends on insurance contributions carried out during employment. Contributions to unemployment insurance and thus unemployment benefits are top-coded. Unemployment benefits $b_{i, t}^{u b}(c)$ in year $t$ are obtained as a specific percentage of net earnings. For the simulation of unemployment benefits $b_{i, t}^{u b}(c)$ hypothetically received if out of work are based on earnings of the current year $t$. Formally unemployment benefits are given by

$$
b_{i, t}^{u b}(c)=s^{u b}(c) \cdot\left(y_{i, t-1}^{w}-t_{i, t-1}^{w}-S_{i, t-1}\right),
$$

where $s^{u b}(c)$ is the percentage of previous net earnings depending on the existence of children $c \in\{0,1\} . s^{u b}(c)$ lies at $60 \%$ for childless individuals $(c=0)$ and at $67 \%$ for parents $(c=1)$. Net earnings are given by gross earnings $y_{i, t}^{w}$ reduced by wage taxes $t_{i, t}^{w}$ and social security contributions $S_{i, t}$.

In order to be eligible for unemployment benefits a person has to have a record of employment subject to social security contributions for at least one year within the last three years (1982-2005) or within the last two years (2006-today). Marginally employed do not contribute to unemployment insurance and are thus not eligible.

The entitlement length depends on the number of months employed subject to social security contributions during the last seven or five years, respectively. For the simulation it is assumed, that individuals eligible for unemployment benefits were employed in total for at least 24 months during the last seven years (1987-2005) or five years (2006-today), respectively, thus being eligible for 12 months unemployment benefits. The length of entitlement is increasing with age. We refrain from increasing unemployment benefit length with age since most of the age-dependent variation applies do older employees not part of our sample anyway.

\section{A.1.2 Unemployment Assistance}

Until 2005, individuals may receive earnings-related unemployment assistance after the exhaustion of unemployment benefits. Unemployment assistance is an insurance payment hinging on social security contributions, but means-tested at the same time. Possible claims for unemployment assistance are reduced by net household income. Net household income is reduced again by an allowance on spouse's earnings equal to 
his hypothetical unemployment assistance claim. The remaining amount decreases the claim of the individual for unemployment assistance which can be expressed as

$$
\begin{aligned}
b_{i, t}^{u a}(c)= & s^{u a}(c) \cdot\left(y_{i, t-1}^{w}-t_{i, t-1}^{w}-S_{i, t-1}\right) \\
& -\left(\left(y_{h, t-1}^{U}-t_{h, t-1}^{U}-S_{j, t-1}\right)-s^{u a}(c) \cdot\left(y_{j, t-1}^{w}-t_{j, t-1}^{w}-S_{j, t-1}\right)\right),
\end{aligned}
$$

where $s^{u a}(c)$ is the percentage of previous net earnings depending on the existence of children $c \in\{0,1\} . s^{u a}(c)$ is at $53 \%$ for childless individuals $(c=0)$ and at $57 \%$ for parents $(c=1) . y_{j, t}^{w}, t_{j, t}^{w}$ and $S_{j, t}$ are spouse's earnings, wage taxes and social security contributions. In sum, only single or individuals with a partner who is a transfer recipient and/or not working receive the full amount of unemployment assistance. Families with children receive a more generous income support. This is the case for both unemployment benefits and unemployment assistance. Unemployment assistance is allowed for one year after which the individual has to renew his claim and prove his neediness again. Under the condition that the claim is admitted unemployment assistance can be granted until the individual's retirement.

\section{A.1.3 Social Assistance}

Means-tested social assistance is based on the needs of the household as a whole with household members being treated as a community (Bedarfsgemeinschaft). Households can be entitled to social assistance if the individual in state $U$ has not contributed (sufficiently) to unemployment insurance in state $E$ (1) or if the claim for unemployment benefits/assistance of the individual in state $U$ is very low (2). In 2005, the Hartz $I V$-reform merges social assistance for those able to work and unemployment assistance to a single system so-called unemployment benefit II (Arbeitslosengeld $I I$ ). Since payments of unemployment benefit II are equivalent to social assistance it is referred to social assistance in the following. Starting in 2005, households additionally can be entitled to social assistance if unemployment benefits of the individual in state $U$ are exhausted (3) with the overall household income not covering household needs.

The household head receives the standard rate of social assistance, whereas other household members only receive a share of the standard rate depending on age. Hence, social assistance increases with the number of persons in the household. The sum of household member shares gives the householdsize-specific factor $f_{h, t}$ which is multiplied by the annual standard rate $s r_{h, t}(r)$. The standard rate $s r_{h, t}(r)$ differs by region $r$ the household is located (West or East Germany) and year $t$. Additionally, housing assistance $h h_{h, t}(r)$ is provided to compensate for rent and heating payments. Possible claims on social assistance $b_{h, t}^{s a}(c)$ are computed as

$$
b_{h, t}^{s a}(c)=f_{h, t} \cdot s r_{h, t}(r)+h h_{h, t}(r)
$$

Potential claims for social assistance are reduced by household income and property as well as unemployment benefits and unemployment assistance. For the simulation it is assumed that household's property does not exceed the exemption limits. Following Bönke and Eichfelder (2010), claims for social assistance after de- 
ductions can be expressed as

$$
\begin{aligned}
b_{h, t}^{s a}(c)= & \operatorname{Max}\left(f_{h, t} \cdot s r_{h, t}(r)+h h_{h, t}(r)-c h_{h, t}(c)\right. \\
& \left.-\operatorname{Max}\left(y_{h}^{U}-t_{h}^{U}+b_{i, t}^{u b}(c)+b_{i, t}^{u a}(c)-\operatorname{Min}\left(L E, y_{h}^{U}\right)-A_{j}, 0\right), 0\right),
\end{aligned}
$$

where $c h_{h, t}(c)$ are child benefits and $A_{j}$ denotes the earnings allowance for spouse $j$ 's earnings $y_{j, t}^{w}$. LE is lump-sum income-related expenses of 100 Euro per month or 1,200 per year, which is granted since 2005. Statutory earnings allowance are subject to reform between the two three-year periods. Allowances 1995-1997 are given as

$$
A_{j, t}= \begin{cases}y_{j, t}^{w} & \text { if } y_{j, t}^{w} \leq 0,25 \cdot s r_{h, t}(r) \\ 0.25 \cdot s r_{h, t}(r)+0.15 \cdot\left(y_{j, t}^{w}-0.25 \cdot s r_{h, t}(r)\right) & \text { if } 0.25 \cdot s r_{h, t}(r)<y_{j, t}^{w} \\ 0.25 \cdot s r_{h, t}(r)+0.15 \cdot\left(y_{j, t}^{w}-0.25 \cdot s r_{h, t}(r)\right) & \text { if } \leq 0.5 \cdot s r_{h, t}(r)\end{cases}
$$

Allowances since 2005 are defined as

$$
A_{j, t}= \begin{cases}0.2 \cdot\left(y_{j, t}^{w}-1,200\right) & \text { if } 1,200<y_{j, t}^{w} \leq 9,600 \\ 0.2 \cdot 8,400+0.1 \cdot\left(y_{j, t}^{w}-9,600\right) & \text { if } 9,600<y_{j, t}^{w} \leq 14,400 \\ 0.2 \cdot 8,400+0.1 \cdot 8,400 & \text { if } y_{j, t}^{w}>14,400\end{cases}
$$

The upper limit of 14,400 Euro increases to 18,000 Euro if children live in the household.

\section{A.1.4 Housing allowance}

Households with an income below a specific threshold can apply for housing allowance instead of social assistance. The payment depends on the number of household members and on household income reduced by lump sum deductions. Housing allowances are computed in accordance to the German Housing Benefit Act (Wohngeldgesetz) following Bönke and Eichfelder (2010) as

$$
b_{h, t}^{h a}=\operatorname{Max}\left(H_{h, t}^{h a}-\left(a_{i}+b_{i} \cdot H_{h, t}^{h a}+c_{i} \cdot H_{h, t}^{h a}\right) \cdot y_{h, t}^{h a}, 0\right),
$$

where $H_{h}^{h a}$ denotes the relevant housing costs, $y_{h}^{h a}$ the relevant net household income and $a_{i}, b_{i}, c_{i}$ the factors in appendix 1 of the Housing Benefit Act. The relevant income for housing benefits $y_{h}^{h a}$ is gross household income $y_{h}^{U}$ reduced by the lump sum for income-related expenses $L E$. The relevant housing costs $H_{h, t}^{h a}$ are calculated equivalently to housing assistance as included in social assistance.

\section{A.1.5 Child benefits}

Households with children receive child benefits depending on the number of children. Child benefits are paid at least until the 18th birthday regardless of the labor market state of the parents. A tax exemption instead of child benefits is granted to households with higher income. In 2005 an additional child benefit (Kinderzuschlag) is introduced to raise the household income of working families above the threshold 
of social assistance. The additional child benefit is conditional on being employed and is so far the only in-work benefit in Germany. Households are eligible for this benefit if household income meets the needs of the parents but not the needs of their children. The maximum benefit lies at 140 Euro per month for children under 18 years living in the same household as their parents and is granted to households where household income is equal to the hypothetical claim on social assistance of the parents only. If income lies above that level, additional child benefit is withdrawn at a rate of $70 \%$. The upper income level for eligibility lies at the social assistance level for the household as a whole including the children.

\section{A.2 Taxes}

Statutory provisions for the calculation of household income taxes and social security contributions are described below.

\section{A.2.1 Social security contributions}

Individual gross earnings is the assessment basis for social security contributions of the employee. Earnings below a threshold are denoted as marginal employment and exempted from social security contributions. The reform in 2003 increases the threshold remarkably from 325 to 400 Euro per month (or 4,800 Euro annually). Up to the earnings threshold the employer pays a flat-rate contribution which does not establish an entitlement to social security payments such as unemployment benefits for the employee.

Earnings exceeding these thresholds are due to social security contributions resulting in high marginal tax rates. With the introduction of a zone with increasing social security contributions for modest incomes in 2005 marginal tax rates for low income earners are cut down. Since then, social security contributions increase for annual earnings between $e_{t}^{1}=4,800$ and $e_{t}^{2}=9,600$ Euro (so-called Midi-Jobs) from about $4 \%$ to about $21 \%$. The overall social security contribution rate does not vary significantly over time. Hence, a contribution rate $s=21 \%$ is applied to calculate social security contributions $S_{j, t}$ for earnings above earnings threshold $e_{t}^{1}=e_{t}^{2}$ between 1995 and 1997 and above $e_{t}^{2}$ between 2005 and 2007, respectively. Above the contribution ceiling $R V B_{t}^{\max }$ of the respective year $t$ contributions are fixed in absolute value. Social security contributions are simulated for a working spouse $j$ when individual $i$ is out of work and in state $U . S_{j, t}$ are given as

$$
S_{j, t}= \begin{cases}0 & \text { if } e_{t}^{1}>y_{j, t}^{w} \\ s \cdot\left(F \cdot e_{t}^{1}+(2-F)\left(y_{j, t}^{w}-e_{t}^{1}\right)\right) & \text { if } e_{t}^{1}<y_{j, t}^{w}<e_{t}^{2} \\ s \cdot y_{j, t}^{w} & \text { if } y_{j, t}^{w}>e_{t}^{2} \\ s \cdot R V B_{t}^{\max } & \text { if } y_{j, t}^{w}>R V B_{t}^{\max }\end{cases}
$$

$F$ is a fixed factor equal to 0.7673 . 


\section{A.2.2 Income tax}

Gross household income is subject to taxes on income if exceeding the exemption limits. Income tax reforms undertaken by the red-green government between 1998 and 2005 reduces average tax rates substantially. The tax burden for low income groups is reduced by decreasing the basic allowance and the minimal marginal tax rate. In the German tax schedule, marginal tax rates increase linearly with income up to a threshold. The top marginal tax rate stays constant for income exceeding that threshold. Both threshold and top marginal tax rate are decreased throughout the reforms reducing the tax burden of high income groups, too. In 2007, taxable incomes exceeding 250.731 Euro are subject to a marginal tax rate of $45 \%$. Calculating the taxable income, a lump sum for income-related expenses $L E$ and a lump sum for special private expenses (Sonderausgaben) $L S$ is deducted. It is assumed that expenses do not exceed these lump-sum deductions. Furthermore, the saver's allowance $S A$ is deducted from asset income which is twice as high for married couples.

Moreover, social security contributions can be partially deducted from taxable income. A time-varying amount $S E_{j, t}^{m 2}$ reflecting social security contributions is deducted from taxable income. Since 2005 tax authorities apply the more favorable of two different calculations of deductions $S E_{j, t}^{m 1}$ and $S E_{j, t}^{m 2}$ ( $\$ 10$ Income Tax Code). Furthermore, the profit share (Ertragsanteil) of social security pensions is added to taxable income. Following Bönke and Eichfelder (2010) the taxable base can be described as

$$
y_{h, t}^{T}=y_{h, t}^{U}-L E-L S-\operatorname{Min}\left(\operatorname{Max}\left(S E_{j, t}^{m 1}, S E_{j, t}^{m 2}\right), S_{j, t}\right)
$$

The income tax $T^{i n c}$ is then computed according to $\S 32 \mathrm{a}$ Income Tax Code. The income tax rate $t_{h, t}^{i n c}$ is calculated by $t_{h, t}^{i n c}=\frac{T_{h, t}^{i n c}}{y_{h, t}^{T P}}$ and is applied to the taxable income. The resulting income tax $T_{h, t}^{i n c}$ is given by $T_{h, t}^{i n c}=t_{h, t}^{i n c} \cdot y_{h, t}^{T}$. Married couples are taxed jointly. Couple's joint taxable income is halved to assess the income tax rate. Then, the resulting income tax is doubled.

\section{A.2.3 Solidarity surcharge}

A solidarity surcharge $T^{S}$ is levied if the income tax surpasses the exemption limit $E L^{S}$. On the first pay level the surcharge is imposed at a higher marginal rate $t^{s *}=20 \%$. Hence, $T_{h, t}^{S}$ is given by

$$
T_{h, t}^{S}= \begin{cases}0 & \text { if } T_{h, t}^{i n c} \leq E L_{t}^{S} \\ \operatorname{Min}\left(T_{h, t}^{i n c} \cdot\left(1+t^{s}\right), T_{h, t}^{i n c}+\left(T_{h, t}^{i n c}-E L_{t}^{S}\right) \cdot t^{s *}\right) & \text { if } T_{h, t}^{i n c}>E L_{t}^{S}\end{cases}
$$




\section{B Additional Figures}

Figure B.1

\section{Earnings decile intervals}

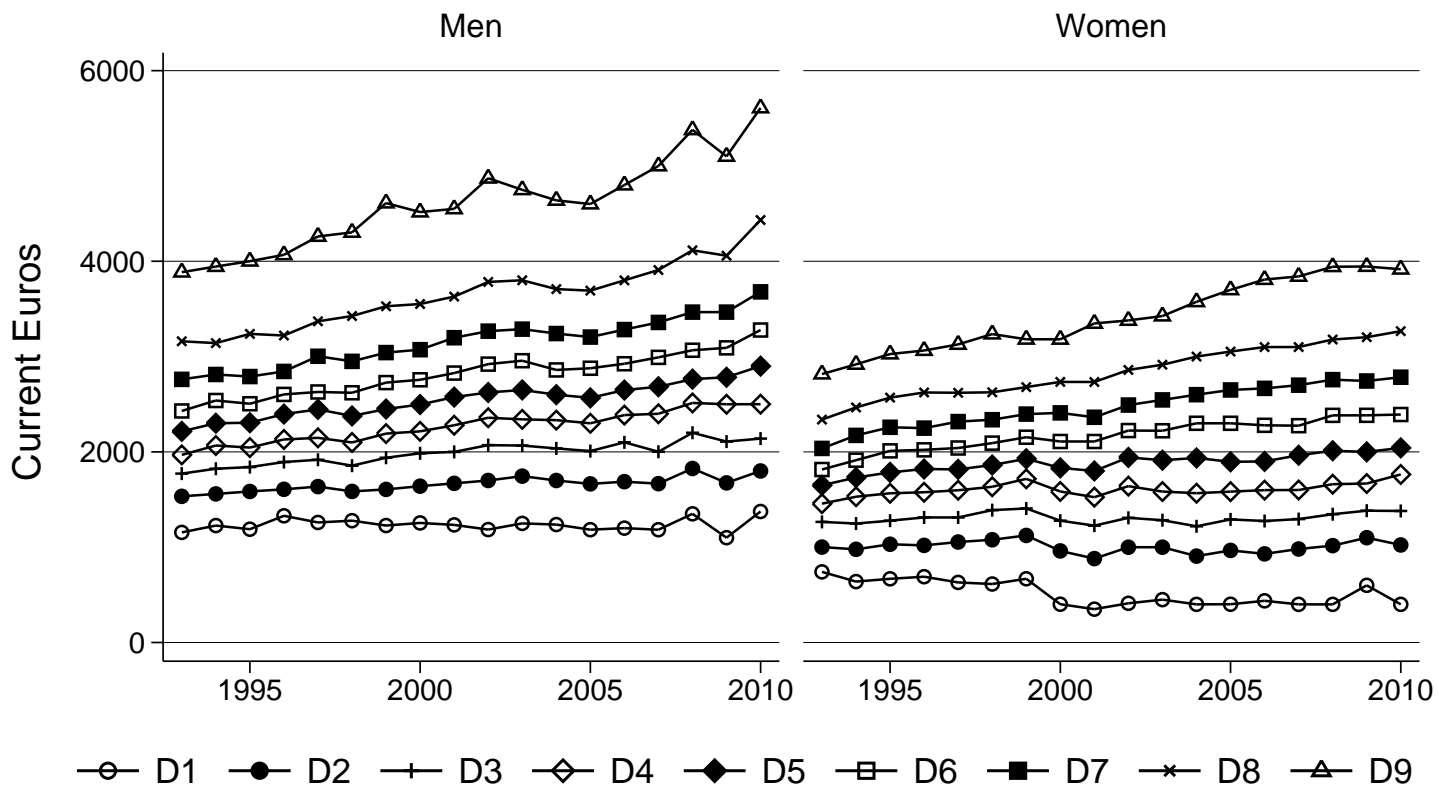

Source: SOEPV29 \& IZA MOD, own calculations. 
Figure B.2

\section{Employment in Germany, 1991-2012}

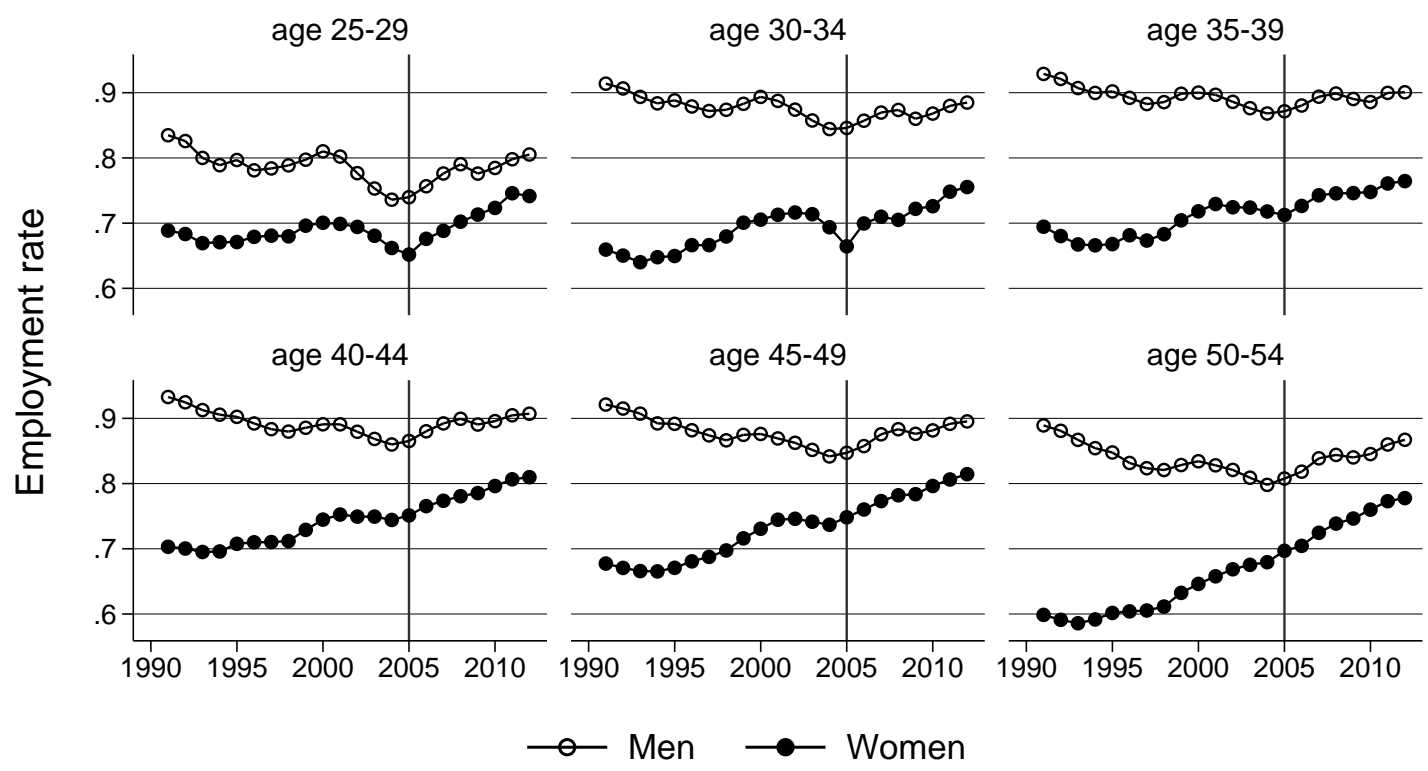

Source: German Microcensus.

Note: Vertical line indicates year of major labor market reform (Hartz IV) in 2005.

\section{Additional Tables}


Table C.1: Effect of short-term PTR on participation (evaluated at 20 hours)

\begin{tabular}{|c|c|c|c|c|}
\hline & \multicolumn{2}{|c|}{ Men } & \multicolumn{2}{|c|}{ Women } \\
\hline & $\begin{array}{l}\text { LOGIT } \\
(1)\end{array}$ & $\begin{array}{l}\text { LOGIT FE } \\
(2)\end{array}$ & $\begin{array}{c}\text { LOGIT } \\
(3)\end{array}$ & $\begin{array}{c}\text { LOGIT FE } \\
(4)\end{array}$ \\
\hline$\Delta$ PTR (short) & $\begin{array}{c}-0.834^{* * *} \\
(0.000)\end{array}$ & $\begin{array}{c}-0.887^{* * *} \\
(0.000)\end{array}$ & $\begin{array}{c}-1.907^{* * *} \\
(0.000)\end{array}$ & $\begin{array}{c}-1.844^{* * *} \\
(0.000)\end{array}$ \\
\hline$\Delta$ PTR $($ short $) \times($ age $35-44)$ & $\begin{array}{c}0.410^{* * *} \\
(0.000)\end{array}$ & $\begin{array}{c}0.130^{* * *} \\
(0.000)\end{array}$ & $\begin{array}{c}0.597^{* * *} \\
(0.000)\end{array}$ & $\begin{array}{c}0.744^{* * *} \\
(0.000)\end{array}$ \\
\hline$\Delta \mathrm{PTR}($ short $) \times($ age $45-54)$ & $\begin{array}{c}-1.002^{* * *} \\
(0.000)\end{array}$ & $\begin{array}{c}-0.401^{* * *} \\
(0.000)\end{array}$ & $\begin{array}{c}0.262^{* * *} \\
(0.000)\end{array}$ & $\begin{array}{c}0.755^{* * *} \\
(0.000)\end{array}$ \\
\hline$\Delta$ PTR (short) $\times \Delta$ U-rate & $\begin{array}{c}0.266^{* * *} \\
(0.000)\end{array}$ & $\begin{array}{c}0.230^{* * *} \\
(0.000)\end{array}$ & $\begin{array}{c}-0.141^{* * *} \\
(0.000)\end{array}$ & $\begin{array}{c}-0.014^{* * *} \\
(0.000)\end{array}$ \\
\hline age $35-44$ & $\begin{array}{c}-0.574^{* * *} \\
(0.000)\end{array}$ & $\begin{array}{c}-0.185^{* * *} \\
(0.000)\end{array}$ & $\begin{array}{c}-0.580^{* * *} \\
(0.000)\end{array}$ & $\begin{array}{c}-0.611^{* * *} \\
(0.000)\end{array}$ \\
\hline age $45-54$ & $\begin{array}{c}-0.779^{* * *} \\
(0.000)\end{array}$ & $\begin{array}{c}0.313^{* * *} \\
(0.000)\end{array}$ & $\begin{array}{c}-0.654^{* * *} \\
(0.000)\end{array}$ & $\begin{array}{c}-0.354^{* * *} \\
(0.000)\end{array}$ \\
\hline$\Delta$ U-rate & $\begin{array}{c}-0.038^{* * *} \\
(0.000)\end{array}$ & $\begin{array}{c}-0.043^{* * *} \\
(0.000)\end{array}$ & $\begin{array}{c}-0.183^{* * *} \\
(0.000)\end{array}$ & $\begin{array}{c}-0.114^{* * *} \\
(0.000)\end{array}$ \\
\hline East & $\begin{array}{c}0.374^{* * *} \\
(0.000)\end{array}$ & $\begin{array}{c}-0.417^{* * *} \\
(0.000)\end{array}$ & $\begin{array}{c}0.174^{* * *} \\
(0.000)\end{array}$ & $\begin{array}{c}-0.132^{* * *} \\
(0.000)\end{array}$ \\
\hline Year FE & Yes & Yes & Yes & Yes \\
\hline Household type FE & Yes & Yes & Yes & Yes \\
\hline Skill level FE & Yes & Yes & Yes & Yes \\
\hline Pseudo- $R^{2}$ & 0.024 & 0.075 & 0.040 & 0.073 \\
\hline $\mathrm{N}$ & $1.02 \mathrm{e}+08$ & 2959 & $1.08 \mathrm{e}+08$ & 4208 \\
\hline
\end{tabular}

Note: P-value indicated in brackets. ${ }^{* * *}=$ significant at the 1 percent level, $* *=$ significant at the 5 percent level, ${ }^{*}=$ significant at the 1 percent level. Household type fixed effects include binary indicators for categories single, single parent, couple (without children) and couple with children. Skill level fixed effects include binary indicators for low, medium and high level of education. 
Table C.2: Effect of short-term PTR on participation (evaluated at 40 hours)

\begin{tabular}{|c|c|c|c|c|}
\hline & \multicolumn{2}{|c|}{ Men } & \multicolumn{2}{|c|}{ Women } \\
\hline & $\begin{array}{l}\text { LOGIT } \\
(1)\end{array}$ & $\begin{array}{l}\text { LOGIT FE } \\
(2)\end{array}$ & $\begin{array}{c}\text { LOGIT } \\
(3)\end{array}$ & $\begin{array}{c}\text { LOGIT FE } \\
(4)\end{array}$ \\
\hline$\Delta$ PTR (short) & $\begin{array}{c}-1.613^{* * *} \\
(0.000)\end{array}$ & $\begin{array}{c}-1.432^{* * *} \\
(0.000)\end{array}$ & $\begin{array}{c}-2.221^{* * *} \\
(0.000)\end{array}$ & $\begin{array}{c}-1.964^{* * *} \\
(0.000)\end{array}$ \\
\hline$\Delta$ PTR $($ short $) \times($ age $35-44)$ & $\begin{array}{c}0.049^{* * *} \\
(0.004)\end{array}$ & $\begin{array}{c}0.012 \\
(0.259)\end{array}$ & $\begin{array}{c}0.310^{* * *} \\
(0.000)\end{array}$ & $\begin{array}{c}0.378^{* * *} \\
(0.000)\end{array}$ \\
\hline$\Delta$ PTR $($ short $) \times($ age $45-54)$ & $\begin{array}{c}-1.180^{* * *} \\
(0.000)\end{array}$ & $\begin{array}{c}-0.339^{* * *} \\
(0.000)\end{array}$ & $\begin{array}{c}0.302^{* * *} \\
(0.000)\end{array}$ & $\begin{array}{c}0.806^{* * *} \\
(0.000)\end{array}$ \\
\hline$\Delta$ PTR (short) $\times \Delta$ U-rate & $0.294^{* * *}$ & $0.392^{* * *}$ & $-0.144^{* * *}$ & $-0.050^{* * *}$ \\
\hline age $35-44$ & $\begin{array}{c}-0.573^{* * *} \\
(0.000)\end{array}$ & $\begin{array}{c}-0.209^{* * *} \\
(0.000)\end{array}$ & $\begin{array}{c}-0.577^{* * *} \\
(0.000)\end{array}$ & $\begin{array}{c}-0.606^{* * *} \\
(0.000)\end{array}$ \\
\hline age $45-54$ & $\begin{array}{c}-0.800^{* * *} \\
(0.000) \\
(0.000)\end{array}$ & $\begin{array}{c}0.269^{* * *} \\
(0.000) \\
(0.000)\end{array}$ & $\begin{array}{c}-0.650^{* * *} \\
(0.000) \\
(0.000)\end{array}$ & $\begin{array}{c}-0.342^{* * *} \\
(0.000) \\
(0.000)\end{array}$ \\
\hline$\Delta$ U-rate & $\begin{array}{c}-0.030^{* * *} \\
(0.000)\end{array}$ & $\begin{array}{c}-0.031^{* * *} \\
(0.000)\end{array}$ & $\begin{array}{c}-0.182^{* * *} \\
(0.000)\end{array}$ & $\begin{array}{c}-0.111^{* * *} \\
(0.000)\end{array}$ \\
\hline East & $\begin{array}{c}0.369^{* * *} \\
(0.000)\end{array}$ & $\begin{array}{c}-0.489^{* * *} \\
(0.000)\end{array}$ & $\begin{array}{c}0.179^{* * *} \\
(0.000)\end{array}$ & $\begin{array}{c}-0.129^{* * *} \\
(0.000)\end{array}$ \\
\hline Year FE & Yes & Yes & Yes & Yes \\
\hline Household type FE & Yes & Yes & Yes & Yes \\
\hline Skill level FE & Yes & Yes & Yes & Yes \\
\hline Pseudo- $R^{2}$ & 0.028 & 0.083 & 0.042 & 0.074 \\
\hline $\mathrm{N}$ & $1.02 \mathrm{e}+08$ & 2959 & $1.08 \mathrm{e}+08$ & 4208 \\
\hline
\end{tabular}

Note: P-value indicated in brackets. ${ }^{* * *}=$ significant at the 1 percent level, $* *=$ significant at the 5 percent level, ${ }^{*}=$ significant at the 1 percent level. Household type fixed effects include binary indicators for categories single, single parent, couple (without children) and couple with children. Skill level fixed effects include binary indicators for low, medium and high level of education. 
Table C.3: Effect of long-term PTR on participation (evaluated at 20 hours)

\begin{tabular}{|c|c|c|c|c|}
\hline & \multicolumn{2}{|c|}{ Men } & \multicolumn{2}{|c|}{ Women } \\
\hline & $\begin{array}{l}\text { LOGIT } \\
\quad(1)\end{array}$ & $\begin{array}{c}\text { LOGIT FE } \\
(2)\end{array}$ & $\begin{array}{c}\text { LOGIT } \\
(3)\end{array}$ & $\begin{array}{c}\text { LOGIT FE } \\
\text { (4) }\end{array}$ \\
\hline$\Delta \mathrm{PTR}$ (long) & $\begin{array}{c}2.540^{* * *} \\
(0.000)\end{array}$ & $\begin{array}{c}-3.092^{* * *} \\
(0.000)\end{array}$ & $\begin{array}{c}-2.232^{* * *} \\
(0.000)\end{array}$ & $\begin{array}{c}-2.460^{* * *} \\
(0.000)\end{array}$ \\
\hline$\Delta$ PTR $($ long $) \times($ age $35-44)$ & $\begin{array}{c}-0.367^{* * *} \\
(0.000)\end{array}$ & $\begin{array}{c}2.727^{* * *} \\
(0.000)\end{array}$ & $\begin{array}{c}5.355^{* * *} \\
(0.000)\end{array}$ & $\begin{array}{c}2.026^{* * *} \\
(0.000)\end{array}$ \\
\hline$\Delta$ PTR $($ long $) \times($ age $45-54)$ & $\begin{array}{c}4.403^{* * *} \\
(0.000)\end{array}$ & $\begin{array}{c}4.221^{* * *} \\
(0.000)\end{array}$ & $\begin{array}{c}-0.445^{* * *} \\
(0.000)\end{array}$ & $\begin{array}{c}-0.410^{* * *} \\
(0.000)\end{array}$ \\
\hline$\Delta$ PTR (long) $\times \Delta$ U-rate & $\begin{array}{c}0.268^{* * *} \\
(0.000)\end{array}$ & $\begin{array}{c}-0.527^{* * *} \\
(0.000)\end{array}$ & $\begin{array}{c}-0.011^{* *} \\
(0.049)\end{array}$ & $\begin{array}{c}-1.139^{* * *} \\
(0.000)\end{array}$ \\
\hline age $35-44$ & $\begin{array}{c}-0.402^{* * *} \\
(0.000)\end{array}$ & $\begin{array}{c}0.915^{* * *} \\
(0.000)\end{array}$ & $\begin{array}{c}-0.720^{* * *} \\
(0.000)\end{array}$ & $\begin{array}{c}-1.071^{* * *} \\
(0.000)\end{array}$ \\
\hline age $45-54$ & $\begin{array}{c}-0.922^{* * *} \\
(0.000)\end{array}$ & $\begin{array}{c}2.701^{* * *} \\
(0.000)\end{array}$ & $\begin{array}{c}-0.540^{* * *} \\
(0.000)\end{array}$ & $\begin{array}{c}-0.926^{* * *} \\
(0.000)\end{array}$ \\
\hline$\Delta$ U-rate & $\begin{array}{c}0.081^{* * *} \\
(0.000)\end{array}$ & $\begin{array}{c}0.218^{* * *} \\
(0.000)\end{array}$ & $\begin{array}{c}-0.306^{* * *} \\
(0.000)\end{array}$ & $\begin{array}{c}-0.196^{* * *} \\
(0.000)\end{array}$ \\
\hline East & $\begin{array}{c}0.557^{* * *} \\
(0.000)\end{array}$ & $\begin{array}{l}-18.706 \\
(0.978)\end{array}$ & $\begin{array}{c}0.534^{* * *} \\
(0.000)\end{array}$ & $\begin{array}{c}0.319^{* * *} \\
(0.000)\end{array}$ \\
\hline Year FE & Yes & Yes & Yes & Yes \\
\hline Household type FE & Yes & Yes & Yes & Yes \\
\hline Skill level FE & Yes & Yes & Yes & Yes \\
\hline Pseudo- $R^{2}$ & 0.054 & 0.240 & 0.057 & 0.159 \\
\hline $\mathrm{N}$ & $4.80 \mathrm{e}+07$ & 1005 & $4.99 \mathrm{e}+07$ & 1260 \\
\hline
\end{tabular}

Note: P-value indicated in brackets. ${ }^{* * *}=$ significant at the 1 percent level, $* *=$ significant at the 5 percent level, ${ }^{*}=$ significant at the 1 percent level. Household type fixed effects include binary indicators for categories single, single parent, couple (without children) and couple with children. Skill level fixed effects include binary indicators for low, medium and high level of education. 
Table C.4: Effect of long-term PTR on participation (evaluated at 40 hours)

\begin{tabular}{|c|c|c|c|c|}
\hline & \multicolumn{2}{|c|}{ Men } & \multicolumn{2}{|c|}{ Women } \\
\hline & $\begin{array}{l}\text { LOGIT } \\
\quad(1)\end{array}$ & $\begin{array}{c}\text { LOGIT FE } \\
(2)\end{array}$ & $\begin{array}{c}\text { LOGIT } \\
(3)\end{array}$ & $\begin{array}{c}\text { LOGIT FE } \\
\text { (4) }\end{array}$ \\
\hline$\Delta \mathrm{PTR}$ (long) & $\begin{array}{c}3.671^{* * *} \\
(0.000)\end{array}$ & $\begin{array}{c}-2.622^{* * *} \\
(0.000)\end{array}$ & $\begin{array}{c}-2.273^{* * *} \\
(0.000)\end{array}$ & $\begin{array}{c}-2.417^{* * *} \\
(0.000)\end{array}$ \\
\hline$\Delta$ PTR $($ long $) \times($ age $35-44)$ & $\begin{array}{c}0.571^{* * *} \\
(0.000)\end{array}$ & $\begin{array}{c}2.603^{* * *} \\
(0.000)\end{array}$ & $\begin{array}{c}6.679^{* * *} \\
(0.000)\end{array}$ & $\begin{array}{c}1.867^{* * *} \\
(0.000)\end{array}$ \\
\hline$\Delta$ PTR $($ long $) \times($ age $45-54)$ & $\begin{array}{c}4.894^{* * *} \\
(0.000)\end{array}$ & $\begin{array}{c}3.089^{* * *} \\
(0.000)\end{array}$ & $\begin{array}{c}-0.519^{* * *} \\
(0.000)\end{array}$ & $\begin{array}{c}-0.644^{* * *} \\
(0.000)\end{array}$ \\
\hline$\Delta$ PTR (long) $\times \Delta$ U-rate & $\begin{array}{c}1.181^{* * *} \\
(0.000)\end{array}$ & $\begin{array}{c}0.092^{* * *} \\
(0.000)\end{array}$ & $\begin{array}{c}0.239^{* * *} \\
(0.000)\end{array}$ & $\begin{array}{c}-1.379^{* * *} \\
(0.000)\end{array}$ \\
\hline age $35-44$ & $\begin{array}{c}-0.408^{* * *} \\
(0.000)\end{array}$ & $\begin{array}{c}0.926^{* * *} \\
(0.000)\end{array}$ & $\begin{array}{c}-0.714^{* * *} \\
(0.000)\end{array}$ & $\begin{array}{c}-1.091^{* * *} \\
(0.000)\end{array}$ \\
\hline age $45-54$ & $\begin{array}{c}-0.873^{* * *} \\
(0.000)\end{array}$ & $\begin{array}{c}2.778^{* * *} \\
(0.000)\end{array}$ & $\begin{array}{c}-0.531^{* * *} \\
(0.000)\end{array}$ & $\begin{array}{c}-0.939^{* * *} \\
(0.000)\end{array}$ \\
\hline$\Delta$ U-rate & $\begin{array}{c}0.076^{* * *} \\
(0.000)\end{array}$ & $\begin{array}{c}0.200^{* * *} \\
(0.000)\end{array}$ & $\begin{array}{c}-0.308^{* * *} \\
(0.000)\end{array}$ & $\begin{array}{c}-0.198^{* * *} \\
(0.000)\end{array}$ \\
\hline East & $\begin{array}{c}0.545^{* * *} \\
(0.000)\end{array}$ & $\begin{array}{l}-19.055 \\
(0.982)\end{array}$ & $\begin{array}{c}0.534^{* * *} \\
(0.000)\end{array}$ & $\begin{array}{c}0.309^{* * *} \\
(0.000)\end{array}$ \\
\hline Year FE & Yes & Yes & Yes & Yes \\
\hline Household type FE & Yes & Yes & Yes & Yes \\
\hline Skill level FE & Yes & Yes & Yes & Yes \\
\hline Pseudo- $R^{2}$ & 0.057 & 0.236 & 0.057 & 0.157 \\
\hline $\mathrm{N}$ & $4.80 \mathrm{e}+07$ & 1005 & $4.99 \mathrm{e}+07$ & 1260 \\
\hline
\end{tabular}

Note: P-value indicated in brackets. ${ }^{* * *}=$ significant at the 1 percent level, $* *=$ significant at the 5 percent level, ${ }^{*}=$ significant at the 1 percent level. Household type fixed effects include binary indicators for categories single, single parent, couple (without children) and couple with children. Skill level fixed effects include binary indicators for low, medium and high level of education. 